\title{
Party System Institutionalization, Accountability and Governmental Corruption
}

\begin{abstract}
Why do repeated elections often fail to curb governmental corruption even in full democracies? While much of the comparative literature on corruption focuses on the institutional features of democracies, this paper argues that party system institutionalization is an additional and neglected factor in explaining why corruption may persist in the context of democratic elections. Under-institutionalized party systems impede accountability. They compromise the capacity of voters to attribute responsibility and undermine electoral coordination to punish incumbents for corruption. We test these expectations by combining a controlled comparative study of 80 democracies around the world with an examination of the causal process in a case study of Panama. The findings suggest that party system institutionalization powerfully shapes the scope for governmental corruption.
\end{abstract}


During the 2013 congressional elections in the Philippines, Gloria Arroyo defeated a challenger from the ruling Liberal Party, Vivian Dabuand, and secured re-election to a second term in Congress despite the fact that she was on trial for corruption. Voters were not helped in their decision by the confusing choice that they faced. Arroyo, a founding member of the KAMPI party, who stood for the independent minority party Lakas, was also honorary chairwoman of the ruling Liberal Party. In the Philippines, even the largest political parties are characterized by frequent party switching and overlapping membership, and voters are confronted with short-term coalition building, as well as numerous party dissolutions and reemergences from each election to the next (Ufen 2007: 13, see also Rocamora 1998, Teehankee 2006). This lack of party system institutionalization not only complicates for voters the task of attributing responsibility for corruption, it also undermines electoral coordination, and thus the ability of voters to employ electoral choice effectively to oust corrupt incumbents and hold their representatives accountable. Filipino voters do not approve of corruption. Sixty-four percent believe governmental corruption to be a serious problem; seventy-five per cent believe that citizens have a role to play in combatting it (Transparency International 2013). Still, the Philippines are the sixteenth most corrupt democracy in our sample of 80.

Realities like this are at variance with the conventional model of democratic accountability, which proposes that elections in principle make the self-interest of public officials and the preferences of the electorate compatible. Regardless of their real motives and intentions, the dependence of politicians on popular support is thought to force them to take electoral preferences into account (Schedler 1999: 20). This model assumes that citizens can use their vote effectively to sanction representatives who do not serve the interests of the electorate. However, empirical evidence drawn from a wide range of democracies demonstrates that freely contested regular elections often fail to secure governance in the interest of the people. 
Elections can help corrupt politicians to power and voters may fail to punish incumbents who engage in or permit malfeasance (Reed 1999, Kurer 2001, Scheiner 2005).

The impact of party systems on the effectiveness of elections has been largely overlooked in the comparative literature, which describes corruption as conditioned primarily by political institutions (an exception is Keefer 2011). This literature examines how free elections and full democratization (Montinola and Jackman 2002, Adsera, Boix and Payne 2003), presidentialism and federalism (Fisman and Gatti 2002, Persson and Tabellini 2003: 23-4, Gerring and Thacker 2004), and also electoral systems affect accountability and clean government (Kunicova and Rose-Ackerman 2005, Chang and Golden 2006).

The reality, however, is that electoral accountability in democracies is not just structured by institutions, but also by the party system (Mainwaring 1993, Samuels and Shugart 2010, Moser and Scheiner 2012). In this study, we show that the institutionalization of party systems plays an additional and neglected role in conditioning the effectiveness of elections as tools for voters to control politicians and to secure clean government. In many democracies around the world, voters face the challenge of controlling their politicians in the context of poorly institutionalized and unstable party systems characterized by short-lived party organizations that compete in changing electoral alliances and with fluid personnel (Zielinski, Slomczynski and Shabad 2005; Lindberg 2007). The difficulties that such systems create for voters in attributing blame for poor performance and removing under-performing incumbents are formidable and have a powerful impact on the scope for corruption.

The effect of party system institutionalization, we argue, goes beyond underlying contextual factors such as electoral rules and social cleavages. To be sure, social diversity and the permissiveness of electoral rules define part of the structural context in which party system institutionalization may (or may not) arise (Amorim Neto and Cox 1997; Clark and Golder 
2006). But the institutionalization of party systems given such contextual features varies greatly (Moser and Scheiner 2012), and reflects contingent political choices by politicians, voters and elites more broadly. Whether parties persist or perish, for instance, is shaped by party leaders' choices and inclinations such as their investment in a strong party organization and their responses to legitimacy problems (for instance, in the post-communist context) (Tavits 2011, 2013). Opportunities for new parties to rise are contingent, reflecting, for example, the strategies adopted by other competitors, endorsements by organised interests beyond the state (such as trade unions), and the financial support available (Boix 2007; Hug 2000; Payne 2002). Similarly, the stability of patterns of party competition is shaped by agency and discretion: Party elites can recast competition in a variety of ways by betraying coalition partners, reversing policy in response to exogenous shocks, or seizing on valence issues (Tavits 2008; Stokes 2001; Bleck and Van de Walle 2013). Moreover, such choices are typically hotly contested precisely because they recast patterns of competition and because it is difficult to predict whether voters will depart from prior behaviour to reward or punish such strategies. In sum, party system institutionalization can be expected to have an independent impact on the effectiveness of elections that extends beyond the influence social cleavages and electoral rules.

We test this argument using a research design that combines the strengths of a controlled comparative analysis of corruption in 80 democracies with an examination of process by which weak party system institutionalization attenuates accountability in a case study of Panama. In order to causally identify the effect of party system institutionalization, we pay particular attention to causal sequencing and reverse causation. Our results reveal powerful effects of the party system on the scope for corruption. Where voters' ability to attribute responsibility and to punish is limited by weakly institutionalized party systems, the otherwise large electoral penalties that voters impose for corruption (up to 13 percent in our 
case study) can effectively be reduced to zero. As a result, the system of repeated elections no longer functions as intended and democracies give greater latitude to corruption.

These findings have ramifications for two central areas of comparative politics. To the comparative literature on the political determinants of corruption we contribute by showing that the scope for corruption cannot be understood as structured by institutions alone, but depends critically on the existence of party systems that allow voters to attribute responsibility and to punish incumbents who fail to address corruption. To the literature on electoral accountability, we contribute the insight that party systems may play a role in shaping the electoral nexus that rivals that of institutions, on which the extant debate has overwhelmingly focussed (Powell 2000, Golder and Loyd 2014).

\section{Conceptualizing Corruption}

We conceptualize governmental corruption as the misuse of public office for personal or political gain, as well as the acquiescence in such misuse by bureaucrats (Key 1936, Tavits 2007). This definition encompasses all forms of governmental corruption - grand and petty forms of theft, bribery and illegal rent-seeking by public officials. Defined in this way, governmental corruption is a public policy outcome, for which politicians are in principle accountable - they may invest resources in fighting it, or tolerate it and possibly even engage in it. ${ }^{1}$

Surveys around the world indicate that a majority of citizens perceive governmental corruption as a deleterious outcome. This is true even in countries where corruption is

\footnotetext{
1 Because governmental corruption (which includes grand corruption), is not directly observable, we operationalize this concept using corruption perceptions. The rationale for this choice is explained below.
} 
endemic so that citizens regularly experience it, and benefit from it in individual instances, as is often the case in highly clientelistic systems. For instance in African democracies, as in other polities in which corruption and clientelism are widespread, decisive majorities of citizens typically regard corruption as morally reprehensible (Persson, Rothstein and Teorell 2010). The 2006 Afrobarometer makes clear that over 60 percent of all African respondents regard corruption by public officials as wrong and punishable (Afrobarometer 2006). That is not surprising. Even when citizens are frequently involved in corrupt exchanges, and benefit from them in specific instances, this does not imply that they normatively approve of governmental corruption, nor does it imply citizen tolerance for illegal rent seeking by politicians.

Surveys also make clear that citizens perceive governmental corruption as an outcome that results when their political agents - elected politicians - fail to address malfeasance. In Transparency International's 2013 Global Corruption Barometer, which polled 114,000 people in 107 countries and territories around the world, respondents ranked political parties as the most corrupt institution overall, and in 88 countries a majority of the respondents perceived their government's efforts in fighting corruption as ineffective (Transparency International 2013: 15-18). For citizens collectively, then, governmental corruption is a principal-agent problem that arises when politicians deviate from the electorate's interests. Voters (the principals) delegate government power to politicians (their agents) to attain certain goals - such as clean government - but self-interested politicians may abuse their office or tolerate malfeasance by bureaucrats (Adsera, Boix and Payne 2003: 447). Under what conditions, then, do politicians act more or less effectively as agents of the electorate?

\section{Shirking, Party System Institutionalization and the Scope for Corruption}


The literature on shirking examines precisely this question. This work is based on the observation that politicians may deviate from voter preferences because expending effort to pursue their principals' concerns is costly (Ferejohn 1986). For example, fighting corruption requires time and resources, for which other policy priorities compete. Likewise, desisting from abuse of office implies foregoing the personal and partisan benefits that politicians may otherwise derive from corruption. When politicians' interests are not well aligned with their electorate, the result can be shirking, defined as "behaviour that differs from what would be observed given perfect monitoring and effective punishment" (Rothenberg and Sanders 2000: 316).

A central finding in the literature on shirking is that representatives deviate from voter preferences when the costs of doing so are low (Figlio 2000). These costs vary with the effectiveness of elections so that transformations of the electoral connection can impact dramatically on the extent to which politicians act in the interest of voters. For example, retirement decisions and constitutional term limits, which sever the electoral connection, have been shown to increase shirking in the US context: Exiting members of Congress represent their constituents less faithfully and participate less (Rothenberg and Sanders 2000); retiring legislators spend substantially more money on foreign travel than their colleagues (Parker and Powers 2002); and state governors who cannot stand for re-election because of term limits are less disciplined in their tax and spending policies (Besley and Case 1995). Although most of this research concentrates on the US, the intuition extends to other cases (Besley and Lacrinese 2010).

We build on the insight that the effectiveness of the electoral connection shapes the incentives and policy choices of politicians, and apply it to the comparative context and to a different domain - corruption control. In a cross-national context, we argue, the effectiveness 
of elections as a means to control and incentivise politicians is critically shaped by party system institutionalization.

Party system institutionalization has two central constituent features - the regularity of competition and the organizational stability of parties within the system (Bartolini and Mair 1990, Mainwaring and Scully 1995, Schedler 1995, Roberts and Wibbels 1999, Mainwaring, Espana and Gervasoni 2009, Hassan 2011: 34). ${ }^{2}$ While well institutionalized party systems feature stable parties and alliances and predominantly constant party affiliations of politicians, poorly institutionalized systems are characterized by the frequent rise of new parties and alliances, the demise of pre-existing ones, a low average party age, high electoral volatility, and frequent party switching by politicians (Roberts and Wibbels 1999, Birch 2003, Shabad and Slomczynski 2004, Kuenzi and Lambright 2005, Sikk 2005, Tavits 2008).

The level of party system institutionalization varies among both young and old democracies. While Taiwan, for instance, quickly established a relatively stable party system (Croissant and Völkel 2010: 15), Russia throughout the 1990s, had a fluid system in which the identity of key competitors changed from election to election (Rose, Munro and White 2001). Similarly, older democracies can suffer crises of representation that result in the extensive deinstitutionalizations of their party systems as in Italy in the 1990s, and Bolivia, Ecuador, Venezuela and Peru during the 1990s and early 2000s (Sanchez 2008).

\footnotetext{
2 The concept was originally developed by Mainwaring and Scully (1995) and refined in subsequent work, which notes that the original conceptualization partially conflated the causes of party system institutionalization (roots in society) and its effects (the legitimacy of parties) with the phenomenon itself (Hassan 2011: 34). We focus here on the two core constituent features of the concept.
} 
This variation in party system institutionalization has implications for the effectiveness of elections as instruments of accountability (Mainwaring and Scully 1995, Schedler 1995, Birch 2003). Electoral accountability depends on two conditions, (i) citizens must be able to attribute responsibility for policy and (ii) "they must have a fair opportunity to cast a meaningful vote for or against the policymakers" (Powell 2000: 51, emphasis added). Party system institutionalization affects both dimensions of accountability, which has implications for shirking and the scope for corruption.

In well-institutionalized systems, in which party organizations persist over time and alliances display some continuity, parties are able to develop clear reputations. This allows voters to (i) distinguish clearly between incumbents and the opposition, and (ii) enhances the informational value of party labels as well as the credibility of policy promises (Keefer 2011). Voters are thereby given the means to attribute responsibility and to unseat corrupt incumbents by co-ordinating on a challenger with a credible commitment to reduce corruption, which raises the costs of shirking.

In contrast, poorly institutionalized party systems attenuate electoral accountability. When party and alliance changes affect the relationship between politicians and voters, voters are presented with an unstable set of choices that may (i) cut across the incumbent-opposition divide established by the previous election, and (ii) conflate the reputations of individual incumbents (who may have switched party), parties (which may have switched alliance partners), and alliances (that may have changed in composition) (Zielinski, Slomczynski and Shabad 2005: 390). As a result, responsibility is obscured: alliance and party changes distance parties (and individual politicians) from their record in office, detach their reputations from those of their former coalition partners (and party), and pool them with new coalition partners (or a new party). This makes effective responsibility attribution and voter co-ordination to punish incumbents who have failed to curb corruption unlikely. The same 
party system features also undermine the credibility of policy commitments to reduce corruption by pooling the non-credible commitments of tarnished incumbents with those of new coalition partners (or a new party) (Keefer 2011). Through each of these mechanisms low party system institutionalization impedes the electoral punishment of corruption and lowers the costs of shirking. ${ }^{3}$

Anecdotally, too, we see that voters are better able to identify and sanction poorly performing incumbents in well institutionalized party systems. For instance, Welch and Hibbing (1997) show that in the US context, a corruption charge costs incumbents nearly 10 percent of the vote, and leads to electoral defeat in 25 percent of the cases - far higher than the rate of defeat among incumbents who had not been charged. Poorly institutionalized party systems, in contrast, diminish the ability of voters to attribute responsibility and to sanction effectively. For instance, the party formed by Brazilian President Fernando Collor de Mello, who resigned in 1992 following charges of corruption and a threat of impeachment, dissolved in the months following his resignation (Mainwaring and Torcal 2006: 217). Similarly, party switching in Poland compromised the ability of voters to hold legislators accountable for poor performance (Zielinski, Slomczynski and Shabad 2005).

Other things equal, then, poorly institutionalized party systems can be expected to increase the scope for shirking and corruption by diminishing the effectiveness of elections as

\footnotetext{
${ }^{3}$ Note that this argument applies in a symmetrical manner to incumbents who perform well in curbing corruption. Poor party system institutionalization equally attenuates their accountability: Well-performing incumbents are not effectively rewarded, poorly performing ones not effectively punished. This attenuation of the link between an incumbent's policy performance and electoral sanctioning increases the scope for corruption.
} 
mechanisms of electoral control and accountability. ${ }^{4}$ This analysis yields two complementary hypotheses. First, at the aggregate cross-national level we anticipate that:

Hypothesis 1: Greater party-system institutionalization reduces governmental corruption.

Second, we expect that the constituent features of party system institutionalization condition the electoral accountability of individual incumbents, so that:

Hypothesis 2: Politicians associated with corruption, who are affected by party and alliance changes, are punished less effectively in elections.

To test these expectations, we combine a cross-national comparative analysis with a nested case study of Panama. The two parts of this research design have complementary strengths. The cross-national analysis contributes external validity by enabling us to test the effect of party-system institutionalization on corruption in a large sample of democracies, taking account of confounding factors. The case study contributes causal process observations. Following Lieberman's recommendations (2004: 444), we select a case that is nested in the cross-national analysis and is well predicted by it, so that the hypothesized causal processes can be expected to operate. Within-case variation enables us to test a crucial part of the causal

\footnotetext{
${ }^{4}$ This argument does not imply that elections in the context of institutionalized party systems are always equally effective as sanctioning devices, merely that they are more effective on average than elections in the context of poorly institutionalized party systems. As the large literature on shirking, which we review above, shows, shirking can occur even in the context of the well-institutionalized US party system when the electoral connection is severed. Variation in information costs and constituent memory can also attenuate the effectiveness of the electoral connection (Lindstädt and Vander Wielen 2011).
} 
process - the effect of party and alliance changes on the extent to which incumbents are held accountable for alleged corruption.

\section{Comparative Analysis}

In testing our hypothesis at the cross-national comparative level, we focus on full democracies, which rank 6 or higher on the Polity Index of Democracy. ${ }^{5}$ Our unit of analysis is the country and the data cover 80 democracies, observed over a seven-year period 20032009 (Appendix 1 details the countries included).

\section{Dependent Variable}

One of the most widely accepted measures of corruption is the control of corruption dimension of the World Bank Governance Indicators (Kaufmann, Kraay and Mastruzzi 2010). These data measure the essentially hidden phenomenon of corruption via a range of surveys of residents of a country, international and domestic business people, and risk analysts. The indicator is designed to record the extent to which public power is exercised for private gain, including petty and grand forms of corruption, as well as "capture" of the state by elites and private interests. The measure embraces perceptions of all the forms of corruption that we wish to capture given that we conceive of governmental corruption as a public policy outcome. The World Bank indicator aggregates these surveys, treating them as measures of a common latent variable, which is estimated using an unobserved components model. In our data, the measure varies from -1.46 (Bangladesh) to 2.35 (Denmark), with higher values corresponding to better corruption control (and thus lower levels of perceived

\footnotetext{
${ }^{5}$ We do not include electoral and partial democracies in the analysis because accountability in these political systems may be compromised ex ante by electoral manipulation and fraud.
} 
corruption). Descriptive statistics for all variables included in the analysis are reported in the Supplementary Information, Table SI 1.

The two critical advantages of this indicator are its breadth of coverage, which is unmatched by any alternative measure, and the variety of sources employed, which makes it less susceptible to poll-specific or question-specific idiosyncrasies. Despite these advantages, though, the data pose several challenges. First, the World Bank indicator's use for longitudinal analysis remains disputed because of changes in the methodology used to construct the index over time (Treisman 2007: 220-221). This concern is particularly pertinent for the period 1996-2002 when the indicator's country coverage, the data sources, and the weighting of those sources change extensively. ${ }^{6}$ Therefore, we do not use the index for the early years, but employ it from 2003 after which the sample, data sources and weightings are significantly more stable. Moreover, while we are sympathetic to Kaufmann, Kraay and Maztruzzi's (2007) argument that the methodological changes (after 2002) are substantively not very important, we apply caution and confine ourselves to cross-sectional analysis of these data. Second, the measure records corruption perceptions rather than the frequency or seriousness of actual corruption and it is possible that corruption perceptions deviate from the underlying phenomenon. Given the covert and illicit nature of corruption, no measures of actual corruption exist for a large enough number of cases to enable crossnational analysis. Surveys that gauge corruption experiences come closest to providing such a measure, but tend to capture only petty rather than political and grand corruption and their coverage of countries and years is as yet too limited. Fundamentally, though, corruption perceptions reflect the underlying frequency of corrupt interactions. As Treisman (2007: 218)

\footnotetext{
${ }^{6}$ Initially, these changes account for over half of the variance in the corruption indicator over time (Kaufman and Kray 2002: 14-15).
} 
reports, the correlation between the World Bank measure of corruption perceptions and the main survey measures of corruption experiences is high and statistically significant, with correlation coefficients that range from .66 to $.79(p=.01)$. To take account of the fact that spikes in corruption perceptions can occur through raised awareness in a particular countryyear, we average corruption perceptions reported for each of the countries in our analysis across a seven-year period (2003-9).

\section{Independent Variable: Party System Institutionalization}

Two measures of party system institutionalization are available for a large enough number of cases to enable comparative analysis: average party age (of the main political parties) and electoral volatility. Both measures of party system institutionalization are widely used in comparative studies and reflect the constituent features of party system institutionalization the organisational stability of parties and the regularity of patterns of competition (Mainwaring and Scully 1995, Roberts and Wibbels 1999, Kuenzi and Lambright 2005, Mainwaring and Zoco 2007). The average age of the main parties is affected by (i) the entry and exit of parties into the political system (i.e. their organisational stability), as well as by (ii) changes in their relative size - which conditions what group of parties is included in the measure (regularity of patterns of competition). Electoral volatility, likewise, reflects (i) the entry and exit of parties and (ii) changes in their electoral fortunes.

Our main analysis relies on the average age of the first and second largest governing parties and the largest opposition party or any subset of these for which party age is known, ${ }^{7}$

\footnotetext{
${ }^{7}$ The focus on the three largest parties is motivated by two considerations. First it captures the institutionalization of the parties which structure the choices of the largest groups of voters. Second, it reduces measurement and coding error in fluid party systems where the organizational history of small parties is often poorly documented.
} 
recorded in the Database of Political Institutions by Beck et al. $(2001) .{ }^{8}$ Because the marginal effect of an additional year can be expected to decrease as average party age rises, we take the natural logarithm of average party age (Appendix 2 details coding decisions and data sources for all variables). ${ }^{9}$ To test the robustness of these results, we replicate the analysis using electoral volatility (full data available for a reduced sample of 52 countries). We employ Mainwaring, Espana and Gervasoni’s (2009) measure for total volatility aggregated over the period $1990-2002,{ }^{10}$ which captures the "absolute value of change in the percentage of votes gained or lost by each party from one election to the next" (Mainwaring, Espana and Gervasoni 2009: 1). As anticipated, average party age correlates highly with volatility ( $r=$ $.64, p=.000)$.

\section{Control Variables}

We employ two sets of control variables that have been shown to affect corruption in previous cross-national work - a more parsimonious set that includes other party system

\footnotetext{
${ }^{8}$ Throughout, we use the 2010 version of Beck et al.'s Database of Political Institutions.

${ }^{9}$ To test the measurement validity of our party age variable, we compare it to more nuanced indices of party system institutionalization developed for specific geographical regions including Latin America (Jones 2005), East and Southeast Asia (Croissant and Völkel 2010) and Africa (Kuenzi and Lambright 2001). Jointly, these indices cover 38 of the countries in our dataset. The indices and our party age measure coincide in their classification of party systems as above-average and below-average institutionalization in 68 percent of the African cases and 64 percent of the Latin American and East and Southeast Asian cases, which suggests that average party age proxies party system institutionalization well.

${ }^{10}$ We record electoral volatility over this extended period in order to capture at least two elections per country.
} 
features, constitutional, economic, political, and regional factors, and a more extensive set that also includes social and electoral system characteristics.

Two features of party systems beyond the level of institutionalization can be expected to affect the scope for corruption: the number of parties and the degree to which competition is ideologically structured. Much of the literature focuses on the corruption-reducing effects of the effective number of electoral parties. When competition is low, the ability of opposition parties to mount a realistic challenge to the incumbent is reduced and as work on Japan and South Africa suggests, this can allow corrupt incumbents to survive in office for prolonged periods of time (Giliomee 1998, Della Porta 2004: 49, Scheiner 2005). We take the natural logarithm of ENEP because the marginal effect of each additional party can be expected to decrease as the number of parties rises (see Appendix 2 for data sources). Second, programmatic party structuration can be expected to affect corruption. Less ideologically structured and more clientelistic forms of competition correlate with higher levels of corruption (Keefer 2011). To measure the ideological structuration of party systems, we draw on Keefer and Stasavage's (2003) data, and follow Keefer's (2011) approach of calculating what proportion of the three largest government parties, and the largest opposition party in a country adopt programmatic policy positions.

Constitutional factors are viewed as a powerful influence on governmental corruption. Constitutions which decentralize power and those that feature executive presidents are characterized by greater competition between political actors and more extensive checks and balances, features that a range of scholars argue limit the scope for corruption (Fisman and Gatti 2002, Persson and Tabellini 2003). Others, however, formulate the opposite expectation (Gerring and Thacker 2004). To control for either possibility, we measure decentralization using Beck (2001) et al.'s coding of the extent to which countries have autonomous, locally 
elected governments and employ an indicator for democracies that feature an executive president drawing on Svolik's (2008) coding.

To take account of the nature of the economy, we control for economic development measured as the natural logarithm of real GDP per capita (in constant 2000 US\$). Development can be expected to curb corruption because it "increases the spread of education, literacy, and depersonalized relationships — each of which should raise the odds that an abuse will be noticed and challenged" (Treisman 2000: 404). Additionally, the ability of officials to extract rents in the domestic market should be reduced when that market is open (Treisman 2000, Gerring and Thacker 2005). Tradeopenness, is measured by the sum of a country's imports and exports as a share of GDP.

The quality and longevity of democracy also affects corruption. We include these two closely related features of democracy as alternative controls - the polity score measuring the quality of democracy in a country (which has been shown to curb corruption), and the age of democracy. $^{11}$

The more extensive set of control variables additionally captures factors which have a theoretical link to party system features, and are expected to shape corruption via electoral choice. First, social cleavages, in particular ethnic and linguistic divisions, are often associated with greater corruption in the literature because corrupt rents can be more easily extracted in divided societies with internal norms and sanctions against betraying co-ethnics. To capture the degree of ethnolinguistic fragmentation we draw on Alesina et. al.'s (2003)

11 Because democracy (age/quality), economic development and average party age are correlated, in particular the former two variables, we orthogonalize these variables in the robustness tests below to examine the effect of party age net of its shared variance with the other two variables. 
index. Second, electoral rules are thought to affect corruption. One argument is that electoral systems, which encourage the cultivation of personal votes - such as plurality elections or open-list proportional representation-lead to greater corruption. The focus on personal reputations gives politicians incentives to differentiate themselves from their co-partisans and "to use illegal proceeds to fund electoral competition" (Chang and Golden 2006: 119). Others disagree and propose that voting for individual candidates in plurality electoral systems make it easier (compared to PR lists) for voters to attribute responsibility and punish corruption (Kunicova and Rose-Ackerman 2005). To account for either possibility, we use a series of indicator variables to record whether a country employs Proportional Representation, Plurality, and Open Lists and include an interaction for open list PR systems (Open List*PR).

\section{Empirical Strategy and Results}

In order to causally identify the effect of party system institutionalization on governmental corruption, we pay particular attention to causal sequencing and reverse causation. These are important concerns because party systems may, in part, be shaped by politicians who wish to protect corrupt practices by limiting the transparency and effectiveness of the choices available to voters. We address this concern in two ways. First, we lag all of our explanatory and control variables by a period of seven years, which significantly outstrips the average period incumbents spend in office in our data. The length of this lag is designed to rule out reverse causation and to separate the incumbent's attributes and record in addressing corruption today (at time $t$ ) from the political choices that affected the party system in the past (at time $t$-7). Since our dependent variable is averaged over a seven-year period (20039), we also average our explanatory and control variables over the corresponding lagged seven-year period (1996-2002). Second, we confront any lingering concerns about endogeneity and reverse causation by instrumenting for party institutionalization 1996-2002, 
using historical party age in the 1980s, and employ two-stage least squares instrumental variable regression as an estimation strategy.

Our dependent variable, the World Bank Control of Corruption Index, is continuous, which makes OLS regression an appropriate model choice. All analyses account for unobserved regional sources of heterogeneity in the levels of perceived corruption by including region fixed effects for the Former Soviet Union, the Middle East, Central and Latin America, Asia, and Africa. ${ }^{12}$

\section{[Table 1 about here]}

Table 1 presents the results of the analysis. ${ }^{13}$ Models 1 and 2 use the parsimonious set of control variables (controlling for the quality and age of democracy respectively), while model 3 includes the more extensive set of controls. All three models show that corruption control improves with party system institutionalization, as anticipated by hypothesis 1 (recall that the World Bank index records corruption perceptions so that higher values indicate better corruption control and thus lower levels of perceived corruption). ${ }^{14}$ This is consistent with

${ }^{12}$ The region fixed effects make a significant contribution to the models' overall explanatory power but do not overwhelm the substantive variables. Without region effects model $\mathrm{R}^{2}$ statistics range from .74 to .79 . The models that include region fixed effects have $\mathrm{R}^{2}$ statistics that range from .87 to .88 .

${ }^{13}$ All statistical analyses are run using STATA 13.

${ }^{14}$ To ensure that our discussion reflects the signs of the coefficients in an intuitive manner, we refer throughout to variables that reduce corruption perceptions (and therefore raise the World Bank measure of corruption control) as improving levels of perceived corruption. Variables that raise corruption perception (and therefore lower the World Bank measure of corruption control) are described as giving rise to poorer corruption scores. 
our argument that institutionalization improves responsibility attribution and assists voters in punishing tainted representatives.

The results of models 1 and 2 are very similar. Model 1 indicates that the effect of party system institutionalization is strongest in young party systems. Thus, holding other variables constant at their means, a rise in average party age from just 4.6 years (Ukraine) by around one standard deviation to 35 years (Czech Republic) correlates with an improvement (i.e., a reduction) of 9.3 percent of the corruption perception score. Predictably, a further one standard-deviation increase in institutionalization of an already well-institutionalized party system to 68 years, the average party age in Sweden, has a diminishing marginal effect and is only associated with an additional improvement of 3.3 percent in corruption perceptions.

Turning to the control variables, both models suggest that corruption scores also respond to other party system features. Ideological party system structuration has a powerful and statistically significant effect in reducing corruption perceptions, the coefficient for the effective number of parties, however, does not reach statistical significance. The control variables that capture constitutional features - decentralized constitutions and the existence of an executive president - both have the positive sign that Persson and Tabellini (2003) and Fisman and Gatti (2002) would expect - indicating that they tend to correlate with improved corruption perception scores - but as previous research has suggested, these effects are fragile and neither coefficient is precisely estimated. Wealth is - as the extant research overwhelmingly suggests - associated with significantly improved levels of perceived corruption. Trade openness never reaches conventional levels of statistical significance. Democracy (both quality in model 1 and age in model 2) is also associated with improved 
levels of perceived corruption, though the coefficient is not always significant in this sample, which consists only of high-quality democracies. ${ }^{15}$

In Model 3, we include the expanded set of controls for ethnolinguistic cleavages and electoral system features to explore how far party system institutionalization retains an independent effect once these underlying structural features are accounted for. As discussed above, these factors have a theoretical connection to party system features, but despite these confounding influences, party system institutionalization retains its significance and substantively sizable effect. All additional controls have the expected signs but the effects are fragile, as the contradictory findings of previous work suggest, and none of these coefficients is estimated precisely enough to reach conventional levels of statistical significance.

Next we confront the concern about the direction of causality and endogeneity in more detail by re-specifying our models 1 and 2, as instrumental variable regressions to guard against the potential problem that OLS estimation produces biased results if the model includes an endogenous regressor. An instrumental variable approach makes causal identification possible when the instrument is correlated with the independent variable (party system institutionalization in 1996-2002) but could not be influenced by the dependent variable (perceived incumbent corruption in 2003-2009) or correlated with its other unobserved causes (Wooldridge 2002, chap. 5). As Sovey and Green (2011: 194) note, lagged values of variables in the model can provide natural candidates for such instruments. We follow this

\footnotetext{
${ }^{15}$ Collinearity is not a concern in estimating any of these models. Mean variance inflation factors for models 1-3 are around 2; the tolerances for average party age are around .57 . The robust relationship between party system institutionalization and corruption is already evident in the simple bivariate correlation between these two variables $r=0.415, p=0.000$ and remains evident when we control for confounding influences in the regression models.
} 
approach and instrument for party system institutionalization in 1996-2002 using average party age in the 1980s. The length of the lag ensures that incumbents - ministers, president and legislators - serving on behalf of parties in the 1980s and 1996-2002 are nearly never the same. The variable is therefore free from the criticism which might apply to temporally more proximate measures - that specific incumbent attributes (such as effectiveness in addressing corruption) have a reverse causal connection with party system institutionalization. It is implausible that incumbent corruption in 2003-2009 could have had an effect on the organizational stability of parties and the stability of patterns of party competition in the 1980s. It is also not likely that historical party system institutionalization is systematically related to corruption perceptions through other unobserved channels. Clientelism, for instance, is accounted for in the analysis as a party system feature that varies independently of party system institutionalization. So, too, are the quality and age of democracy, two fairly robust predictors of the level of perceived corruption. ${ }^{16}$ Average party age in the 1980 s is a strong instrument, which correlates highly with party system institutionalization in 1996$2002(r=.66, p=.000)$.

\section{[Table 2 about here]}

Instrumental variable regression (IV2SLS) proceeds in two stages. At the first stage a new variable is estimated from the instrument (average party age in the 1980s) and the covariates to replace the endogenous regressor. These predicted values are then used in the second stage to isolate the exogenous effects of party system institutionalization on corruption. Table 2 reports the results of the instrumental variable equivalents of our main models 1 and 2 in

\footnotetext{
${ }^{16}$ Clearly, though, our instrument is not randomly assigned. The absence of an unobserved link between historical party age and perceived levels of corruption in 2003-9 is therefore a matter of argument rather than design.
} 
Table $1 .{ }^{17}$ The first stage estimates (columns 1 and 2 ) show that average party age in the 1980s is a strong predictor of party age in 1996-2002. The coefficients for this variable are large and statistically significant; the partial $R^{2}$ statistics (.397 and .354 respectively) indicate that its contribution to explained variance at the first stage is sizable, and the $F$-tests confirm that the instrument cannot be excluded from either model (test statistics are reported at the bottom of columns 3 and 4).

Columns 3 and 4 report the results of the second stage IV2SLS regressions in which party system institutionalization is replaced with the predicted values that were estimated at the first stage. The coefficients for party system institutionalization in these models represent unbiased estimates, purged of any potential endogenous effects. As the results make clear, party system institutionalization retains its statistical significance in the instrumental variable regressions in both models, which control for the quality of democracy (column 3) and its age (column4) respectively. The coefficients for party system institutionalization are slightly larger respectively than in the original OLS models. Substantively, these results confirm that party system institutionalization has a powerful and robust exogenous effect in improving corruption perceptions.

Note that a Durbin-Wu-Hausman test for endogeneity does not reject the null hypothesis that average party age in is exogenous in both models (bottom row Table 2). Put differently, econometrically there is no evidence of endogeneity. This makes OLS the more efficient form of estimation, and we focus on Model 2 (cf. Table 1) in further probing the robustness of the results.

\section{Robustness}

${ }^{17}$ Using lagged party age in the 1980 s reduces the number of observations in the analysis to 66. 
We test the robustness of the results from our main model 2 (cf. Table 1) to four further alternative specifications (results are reported in Supplementary Information SI 2). First, we change our main explanatory variable, and employ electoral volatility instead of average party age as our measure of party system institutionalization. Party systems that display higher levels of volatility are less institutionalized and are, as anticipated, associated with significantly poorer corruption control. Second, we address the fact that party system institutionalization, the age of democracy and wealth are correlated by orthogonalizing these three variables and replacing party system institutionalization with the residuals from the auxiliary regression. This procedure attributes all shared variation between party system institutionalization, wealth and democracy to the two latter variables and allows us to examine the effect of party system institutionalization on perceived corruption, net of that shared variance (Clarke and Stone 2008). As a result, the coefficients on wealth and age of democracy increase in size while the coefficient for party system institutionalization is slightly reduced, but the effect remains sizable and statistically significant. Third, we change our definition of democracy, and successively restrict the sample to focus on increasingly high quality democracies. In a first step we apply a polity threshold of 7, and in a second step a threshold of 8 . The results are robust to all of these alternative specifications.

In sum, the comparative analysis suggests that party system institutionalization has a substantively large and empirically robust effect on perceived levels of corruption as hypothesis 1 anticipates. In the next section we turn to the task of testing our conceptualization of the causal process that accounts for this effect.

\section{Nested Case Study: Panama}

Our theoretical argument suggests that the two constitutive aspects of weak party system institutionalization - irregular patterns of party competition and the organizational instability 
of parties - mediate and undermine electoral accountability, and thereby increase the scope for corruption. In this section of the paper we change the level of analysis and focus on a single case to test our second hypothesis, which focuses on this mediation effect.

We employ a nested research design in which the results of the cross-national analysis are used to guide the selection of the case study (Lieberman 2005). When nested analysis is used for model testing, the case should be well predicted and representative of the larger sample (rather than an outlier), so as to be informative about the anticipated causal processes. Panama's perceived corruption score (-.30) is predicted exactly by model 2 in Table 1 . Table 3 reports the comparisons of Panama's values on the explanatory and control variables in model 2 with sample mean values in the comparative data. As is consistent with Panama's poor corruption score, the lagged average party age (1996-2002) is just 12.5 years, around half of the sample mean of 24.6 years. Other control variables are close to the mean (modal) values in our cross-national data (though it is impossible to achieve a perfect match). Crucially, the case combines a weakly institutionalized party system with meaningful withincase variation in the extent to which that weakness affects the accountability relationship between individual members of parliament and voters. As far as possible, our case selection strategy and research design therefore seek to isolate the impact of party system institutionalization on accountability and corruption.

\section{[Table 3 about here]}

We begin by showing that all constitutive aspects of weak party institutionalization are in evidence during the period that we study. 
We observe Panama between 1999 and 2009, after re-democratization in the wake of the 1989 US intervention that deposed General Noriega. In the early 1990s, the former ruling party's (Partido Revolucionario Democratico, PRD) tainted status and ties to the 20-year long dictatorship motivated the entry of a large number of new parties into the system. However, even as Panama's democracy grew more mature, the party system remained poorly institutionalized.

Throughout the period of our study, the constitutive elements of weak party system institutionalization are manifest. First, patterns of party competition are unstable: Between 2 and 6 parties exit the system in each election, and an average of 3.23 new parties enter, significantly changing the choices that confront voters every five years (Guevara Mann 2011). Electoral alliances among parties are ephemeral. Table 4 reports the alliances in which parties contested elections between 1994 and 2009. While the PRD (which has its roots in the period of military rule) and the PPAN typically form the core of two alliances, other parties switch frequently from one election to the next. In every election, therefore, voters are faced with different sets of alliances, which often combine previous incumbents with some of their erstwhile opponents. Second, party organizations are weak and rates of party switching among legislators are high. A sizable share of these switches is driven by the dissolution of parties and the formation of new ones (Guevara Mann 2000, authors' own calculations). Since 1989, fully 22 to 35 percent of Panama's legislators have switched parties from one election to the next. A critical aspect of our case is variation in the extent to which weak party system institutionalization affects the relationship between voters and individual politicians. While some legislators are affected by party or alliance changes, others are not. We exploit that variation to test our second hypothesis that the constituent features of weak 
party system institutionalization - party and alliance changes - mediate and reduce electoral accountability for corruption.

\section{[Table 4 about here]}

\section{Alternative Explanations}

Before proceeding to the analysis, three potential alternative explanations for corruption in Panama require attention: cultural tolerance of corruption, the level of public information about corruption and the electoral system.

Governmental corruption in Panama is not explained by cultural tolerance of it. Corruption has been a salient concern for voters since re-democratization. Panama's poor rankings in the corruption perception indices compiled by the World Bank and Transparency International capture the local view of corruption well: 88 percent of Panamanians see corruption as widespread (Latin American Public Opinion Project 2010) and 50 percent rate it as the country's biggest problem (LAPOP 2010). Over 58 percent believe that corruption is prominent among politicians (Lationbarometro 2008). Corruption tolerance among citizens is low and on a par with significantly less corrupt Latin American countries such as Uruguay 88 percent of Panamanian respondents disagree that paying a bribe is sometimes justified (LAPOP 2010). Moreover, Panamanian voters translate their values and perceptions into action. While legislative incumbents who were associated with corruption allegations on average lost 1,149 votes between the elections that we focus on in this study (2004 and 2009), those who were not subject to such allegations gained an average of 35 votes.

Governmental corruption can also not be attributed to a lack of public information about the problem. Voters can easily obtain information about corruption. The media in Panama are free (Reporters without Borders, 2011). The main national newspapers regularly report on 
political and governmental corruption and corruption has been a prominent issue in every election campaign. Indeed, governing parties have regularly launched anti-corruption initiatives in the run-up to elections.

Finally, Panama's electoral system facilitates the attribution of responsibility and effective electoral sanctioning. Panama has a small, unicameral legislature (79 members in 2004, 71 in 2009) and employs a mixed electoral system that combines 26 single member districts with the election of legislators by open list proportional representation (PR), mostly in small districts (district magnitude 2 predominates among the 13 PR districts, but individual districts are larger, the largest has a magnitude of 8). The average district magnitude is 1.8 . Notwithstanding other disagreements about the incentives generated by electoral systems, previous studies agree that single member and small open list districts afford voters the ability to attribute responsibility and to punish (Kunicova and Rose Ackerman 2005, Chang and Golden 2006). The electoral system, therefore, should not present obstacles to voters in holding their representatives accountable for corruption.

The puzzle, then, is that despite the high levels of voter concern about corruption, its electoral salience, media information and an electoral system that makes possible effective punishment, Panamanian voters regularly re-elect a significant proportion of national legislators who are subject to corruption allegations.

\section{Data and Dependent Variable}

To what extent does low party system institutionalization account for this puzzle? To answer this question we examine the electoral performance of all legislators who served in the 1999- 
2004 and 2004-2009 legislatures and stood for re-election, 114 in total. ${ }^{18}$ The data are organised as legislator-election panels. The analysis employs two equally plausible dependent variables, the vote share won by the incumbent and the percentage change in that vote share. Descriptive statistics for all variables included in the analysis are reported in the Supplementary Information, Table SI 3.

\section{Explanatory Variables}

To measure the information that voters had about corruption among their representatives we focus on media coverage in the two major national daily newspapers with digital archives El Panama America and La Prensa. Both dailies regularly report allegations of corruption. The availability of digital archives for these papers restricts the scope of our investigation to deputies who served in the 1999-2004 and 2004-2009 legislatures.

In constructing our measure of corruption, we searched all articles that fall into the two legislative periods for items that included both the legislator's name and the word "corruption." We then analysed the content of the article to ensure its relevance to our analysis. As is consistent with our definition of corruption, we counted all instances in which deputies were alleged to be involved in the misuse of public office for personal or political gain or to have tolerated corruption by bureaucrats. This search yielded a total of 390 articles, with an average of 5.7 stories per corruption allegation. In the two legislative periods $E l$ Panama America identifies 39 incumbents as associated with corruption, the corresponding figure for La Prensa is 33. Overlap in the corruption allegations reported by the two papers is high. Both papers jointly report allegations about 30 legislators, 21 percent of all incumbents serving between 1999 and 2009. Because the two papers differ in their political leanings, we

${ }^{18}$ In total 147 legislators were elected, but only 114 stood for re-election. Legislators who were implicated in corruption allegations were not more likely to retire than other legislators. 
record corruption allegations in two different ways. Our first measure is a count only of those instances and allegations of corruption which are reported in both papers (corruption allegations (both papers)). The second measure counts all corruption allegations reported jointly and separately by the two newspapers (corruption allegations (either paper)). Counts of corruption allegations vary between 0 and 65 per deputy.

Our second explanatory variable is an indicator variable for Party/Alliance Change (1, otherwise 0 ). It records whether the relationship between voters and each individual legislator in each election is affected by the constituent features of low part system institutionalization either electoral alliance changes (unstable patterns of competition), or party switches (the weakness of party organizations), or both. In our data, party and alliance changes affect just under a quarter of all legislators (24 percent). Testing hypothesis 2 , that accountability for corruption is mediated by these features of party system under-institutionalization, requires that we interact party/alliance change with corruption allegations.

\section{Controls}

Guided by the literature on incumbent re-election, we take account of four types of confounding influences on the vote share won by deputies (Kiewiet and Zeng 1993, Moore and Hibbing 1998, Theriault 1998, Chang, Golden and Hill 2010, Eggers and Fisher 2011). First, we capture features of their constituency. Electorates in Urban Constituencies are larger, younger and more mobile, which may generate greater vote share swings. We control for the intensity of district level competition. As the Number of Candidates in a District rises, the vote share won by individual candidates should on average be reduced. Second, we record features of the party on behalf of which an MP has served. Serving with the main governing party typically carries an electoral penalty. Hence we include membership of the Core 
Governing Party, which controls the largest number of seats in the governing alliance. ${ }^{19} \mathrm{We}$ also account for the effect of membership of the leading opposition party on an MP's vote share (Major Opposition Party). Third, we control for incumbent-specific features, including whether they hold a Senior Legislative Position as party leaders or assembly president, whether they have a long established relationship with their constituency (Terms in Office), and their Age. ${ }^{20}$ The analysis also takes account of a central performance measure - the Unemployment rate in the MP's district at the time of re-election. In the regressions that focus on vote share instead of vote share change we control for previous incumbent support (Vote Share (previous election)). Appendix 2 details the coding choices and data sources.

\section{Party System Institutionalization and Accountability for Corruption Allegations}

We are now in a position to analyse the effectiveness of accountability for alleged corruption when deputies are (and are not) affected by alliance and party changes. ${ }^{21}$ As indicated in hypothesis 2 , we expect voters to punish corruption allegations, but anticipate that their ability to do so is diminished in the presence of party and alliance changes. Hence, we expect that corruption allegations to have a negative effect on the electoral performance of deputies and that party and alliance changes mitigate this negative effect. ${ }^{22}$

\footnotetext{
${ }^{19}$ In Panama, core governing party status alternates between PPAN and PRD (cf. Table 4).

${ }^{20}$ We were able to establish the age of only 75 percent of the legislators. The ages of the remaining 25 percent were imputed, using STATA's "impute" command.

${ }^{21}$ There is no statistically significant difference in the proportion of corrupt deputies in these two groups $(.23$ and $.18, p=.5258)$.

${ }^{22}$ Berry, Golder and Milton (2012) recommend that researchers test their expectations about the marginal effects of all variables associated with an interaction term. We anticipate that
} 
We model our two dependent variables (incumbent vote share change and incumbent vote share) using ordinary least squares regression and report all coefficient estimates with robust standard errors, clustered on election.

\section{[Table 5 about here]}

Table 5 presents the results of the analysis. Models 1 and 2 examine how low party system institutionalization mediates the effects of corruption allegations on the change in the incumbent's vote share from one election to the next, models 3 and 4 focus on the straightforward vote share of the incumbent. ${ }^{23}$ For each pair of models the first column (models 1 and 3) employs only the count of corruption allegations reported in both papers (corruption alleg. (both)), the second model (models 2 and 4) employs the count of all allegations reported jointly and separately by the two newspapers (corruption alleg. (either)).

The results indicate that voters punish alleged corruption when they can attribute responsibility and exercise effective electoral choice, but their ability to punish is diminished when party or alliance changes intervene. Note that corruption allegations damage electoral performance, as indicated by the negative coefficient, but the interaction term between alleged corruption and party/alliance change always has a positive sign, which detracts from that negative effect. The bottom row of the table sheds light on these interactions. It reports the $p$-values of Wald tests, which examine whether the net effect of corruption allegations is different from zero given party or alliance changes. The tests show that when low party party/alliance switches always compromise the ability of voters to hold their representatives accountable. This should be true for all levels of corruption. In SI 4, we present the additional hypothesis and test it.

${ }^{23}$ Collinearity is not a concern in estimating these models. Mean variance inflation factors for models $1-4$ are range from 2.85 to 2.97 . 
system institutionalization interferes, the statistical significance of corruption allegations drops below conventional levels. Put differently, party and alliance changes mediate and powerfully weaken electoral accountability for corruption allegations, as hypothesis 2 suggests. As table 5 shows, this result is robust across both specifications and dependent variables.

Figure 1 plots the marginal effect of a corruption allegation based on model 1 for the two values of party/alliance change (i.e., 0 and 1). ${ }^{24}$ The figure shows that the effect of a one-step increase in corruption allegations is negative, sizable and statistically significant only when accountability of a deputy is not affected party and alliance changes. Under these circumstances, deputies lose around .2 percentage points of their vote share for each additional corruption allegation. Thus, counts of 20, 40 and 65 corruption allegations (the maximum observed value in our data) give rise to predicted vote share penalties of $-3.95(p=$ $.082),-8.06(p=.037)$ and -13.19 percent $(p=.021)$ respectively. However, when party and alliance changes attenuate electoral accountability, these penalties never reach conventional levels of statistical significance and are effectively reduced to zero. Low party system institutionalization, then, undermines electoral accountability for corruption precisely as hypothesis 2 anticipates.

\section{[Figure 1 about here]}

Other variables behave as expected. As electoral competition becomes more intense and additional candidates enter the race, MPs suffer greater vote share losses (models 3 and 4). Legislators with well-established relationships with their constituencies secure an average vote share bonus of over 3 percent for each additional term served (models 3 and 4). Across

${ }^{24}$ The figure and all marginal effects calculations are produced using STATA's margins command. 
the two elections, the lack of popularity of the major opposition parties leads to an average vote share loss of around 6 percent for legislators affiliated with them (models 1 and 2), and older MPs suffer greater electoral losses than their younger peers (models 3 and 4). Other variables including the main effect for low party system institutionalization have no statistically significant effects on vote share changes.

These results lend unequivocal support to hypothesis 2 - while Panamanians punish corrupt incumbents when they are able to attribute responsibility and to cast an effective vote, party and alliance switches reduce their capacity to sanction. The contrast demonstrates that poor party system institutionalization increases the scope for corruption via the process that we identified theoretically - electoral accountability.

In closing we return to the concern of reverse causation. Could corruption in Panama be the cause of the persistence of party system under-institutionalization? If this were the case we would expect to see a significant correlation between deputies against whom there are corruption allegations and those affected by party or alliance changes, but there is no correlation between these two groups $(r=.06, p=.525)$. Party system underinstitutionalization in Panama has long-running historical and social causes which have weakened parties as organizations and vehicles of effective political competition. The frequency with which parties form and dissolve, MPs change party affiliations, and parties change alliances has created an environment in which corruption can flourish, but it does not seem to be an environment that is caused by corruption in the time period that we study.

\section{Conclusion}

These findings contribute to two important literatures in comparative politics: work on democratic accountability and the literature on the political determinants of corruption. A 
central assumption of conventional models of democracy is that regular elections make politicians responsive to voter preferences. It is this mechanism by which democracy is supposed to contain corruption and to ensure that politicians govern in the interest of the electorate. Yet in reality, governmental corruption varies tremendously even in established democracies. Only in a subset of these democracies are elections effective instruments of accountability in the hands of voters.

Our analysis in this paper offers the first systematic empirical evidence to show that party system institutionalization critically conditions the scope for corruption by affecting the quality of the electoral connection between voters and politicians. Weak party system institutionalization, we propose, erodes the ability of voters to control their representatives through regular elections and undermines the incentives for politicians to curb governmental corruption and to act in the interest of their electorate. Giving careful attention to causal sequencing, reverse causation and the causal mechanisms, we test the observable implications of this proposition at the aggregate cross-national level and at the level of individual incumbent-voter relationships. The controlled comparative analysis suggests that our argument has external validity, and that party system institutionalization has a substantively large and robust effect on perceived levels of corruption across 80 democracies around the world. We then focus on a nested case study of Panama for a process-oriented test, which shows that irregular patterns of party competition and organizationally unstable parties have precisely the meditating effect on electoral accountability that we envisage theoretically. When party system institutionalization affects accountability relationships, it can reduce the very large electoral penalties that voters will otherwise impose for corruption (up to 13 percent in the case of Panama) effectively to zero. Taken together, the results of both analyses suggest that the system of repeated elections requires institutionalized party systems in order to function effectively. It is through stable patterns of party competition and the 
organizational stability of parties that elections turn into effective mechanisms for voters to align the interests of their representatives with their own and to reduce the scope for governmental corruption.

From this finding derives the central implication of our work: The literatures on the political determinants of corruption and electoral accountability have stressed the importance of institutions - both constitutions and electoral systems - in explaining why accountability sometimes fails. Our analysis shows that the nature of the party system is an additional and neglected factor in explaining the effectiveness of democratic accountability. That is, in achieving a more nuanced and accurate understanding of how well accountability in democracies works, attention to the party system is crucial. 
Table 1: Party System Institutionalization Effects on Coruption Perceptions (averaged 2003-2009)

(1) (2) (3)

Ordinary Least Squares Regression

\begin{tabular}{|c|c|c|c|}
\hline Party System Institutionalization (ln Party Age) & $\begin{array}{c}0.176^{* *} \\
(0.069)\end{array}$ & $\begin{array}{c}0.149 * * \\
(0.072)\end{array}$ & $\begin{array}{c}0.150^{* *} \\
(0.075)\end{array}$ \\
\hline \multirow[t]{2}{*}{ Effective Number of Electoral Parties } & 0.211 & 0.197 & 0.223 \\
\hline & $(0.133)$ & $(0.134)$ & $(0.139)$ \\
\hline \multirow[t]{2}{*}{ Ideological Structuration } & $0.638 * * *$ & $0.611 * *$ & $0.628 * *$ \\
\hline & $(0.237)$ & $(0.236)$ & $(0.244)$ \\
\hline \multirow[t]{2}{*}{ Decentralization } & 0.048 & 0.017 & 0.066 \\
\hline & $(0.070)$ & $(0.068)$ & $(0.078)$ \\
\hline \multirow[t]{2}{*}{ Executive President } & 0.036 & 0.048 & 0.039 \\
\hline & $(0.119)$ & $(0.120)$ & $(0.127)$ \\
\hline \multirow[t]{2}{*}{ Tradeopenness } & 0.093 & 0.099 & 0.095 \\
\hline & $(0.137)$ & $(0.136)$ & $(0.145)$ \\
\hline \multirow[t]{2}{*}{ GDP per capita (ln) } & $0.398 * * *$ & $0.406 * * *$ & $0.411 * * *$ \\
\hline & $(0.069)$ & $(0.066)$ & $(0.084)$ \\
\hline \multirow{2}{*}{ Democracy (polity score) } & 0.084 & & 0.081 \\
\hline & $(0.052)$ & & $(0.054)$ \\
\hline \multirow[t]{2}{*}{ Democracy (age) } & & $0.100^{*}$ & \\
\hline & & $(0.059)$ & \\
\hline \multirow[t]{2}{*}{ Ethnolinguistic Fragmentation } & & & -0.176 \\
\hline & & & (0.309) \\
\hline \multirow[t]{2}{*}{ Proportional Representation } & & & 0.138 \\
\hline & & & $(0.135)$ \\
\hline \multirow[t]{2}{*}{ Plurality (First-past-the-post) } & & & 0.187 \\
\hline & & & $(0.209)$ \\
\hline \multirow[t]{2}{*}{ Open Lists } & & & 0.102 \\
\hline & & & $(0.153)$ \\
\hline \multirow[t]{2}{*}{ Open Lists*Proportional Representation } & & & -0.112 \\
\hline & & & $(0.258)$ \\
\hline \multirow[t]{2}{*}{ Constant } & $-4.991 * * *$ & $-4.447 * * *$ & $-5.099 * * *$ \\
\hline & $(0.618)$ & $(0.631)$ & $(0.703)$ \\
\hline Region Dummies & Yes & Yes & Yes \\
\hline R-squared & 0.850 & 0.851 & 0.856 \\
\hline Observations & 80 & 80 & 80 \\
\hline
\end{tabular}

Note: The dependent variable is perceptions of corruption control; standard errors in parentheses; $* \mathrm{p}<.10, * * \mathrm{p}<.05, * * * \mathrm{p}<.01$ (two-tailed test). 
Table 2: Instrumental Variable Analysis (Two Stage Least Squares)

IV Regression

Stage 1

Stage 2

$$
\begin{gathered}
\text { DV }=\text { Party Age }(1996-\quad \text { DV }=\text { Corruption } \\
\text { Perceptions }
\end{gathered}
$$
(1)
(2)
(3)
(4)

Party System Institutionalization (ln Party Age)

$0.192 * 0.219 * *$

Party System Institutionalization (ln, Party Age 1980s)

$0.617 * * * \quad 0.606 * * *$

(0.105) (0.104)

Effective Number of Electoral Parties

$(0.114) \quad(0.102)$

Ideological Structuration

$-0.359-0.421 * *$

$0.219 \quad 0.244^{*}$

$(0.222) \quad(0.200)$

(0.144)

(0.144)

(1)

$0.004 \quad-0.138$

$0.754 * * * \quad 0.716 * * *$

Decentralization

$(0.397)$

(0.363)

(0.224)

(0.225)

0.028

0.005

0.095

0.046

Executive President

(0.118)

(0.101)

(0.068)

(0.062)

0.163

0.226

0.087

0.090

(0.190)

(0.173)

(0.107)

(0.107)

Tradeopenness

0.158

0.175

0.089

0.095

(0.205)

(0.187)

(0.117)

(0.116)

GDP per capita (ln)

0.187*

0.072

$0.348 * * *$

$0.350 * * *$

Democracy (polity score)

(0.111)

(0.097)

(0.064)

(0.060)

0.049

$0.105 * *$

(0.088)

(0.051)

Democracy (age)

$0.263 * * *$

$0.109 *$

Constant

(0.078)

(0.057)

Region Dummies

$-0.752$

0.124

(1.090)

(1.004)

$-4.957 * * *-4.397 * * *$

Yes

Yes

(0.585) (0.624)

$\mathrm{R}^{2}$

partial $\mathrm{R}^{2}$ (avg. party age 1980s)

$0.599 \quad 0.667$

Yes

Yes

F (avg. party age 1980s)

$0.354 \quad 0.397$

$29.04 \quad 34.99$

$(0.000) \quad(0.000)$

Durbin-Wu-Hausman endogeneity test ( $p$-value) 0.595 0.865

Observations 66 66

66

66

Note: The dependent variable (stage 2) is perceptions of corruption control; standard errors in parentheses; $* \mathrm{p}<.10, * * \mathrm{p}<.05, * * * \mathrm{p}<.01$ (two-tailed test). 
Table 3: Panama compared to Sample Mean (and Modal) Values

\begin{tabular}{lcccc}
\hline & \multicolumn{3}{c}{ Sample $^{\dagger}$} & \multicolumn{2}{c}{ Panama } \\
Variable & Mean (Mode) & Min & Max & Mean (Mode) \\
\hline Corruption Perceptions & 0.34 & -1.46 & 2.35 & -0.30 \\
Party System Institutionaliz'n (ln Avg. Party Age & 3.19 & 1.13 & 5.00 & 2.53 \\
Effective Number of Electoral Parties (ln) & 1.43 & 0.52 & 3.30 & 1.92 \\
Ideological Structuration & 0.84 & 0 & 1 & 0.60 \\
Decentralization & 0.98 & 0 & 2 & 1 \\
Executive President & 0.59 (Mode: 1$)$ & 0 & 1 & 1 \\
Tradeopenness & 0.78 & 0.19 & 2.05 & 1.45 \\
GDP per capita (ln) & 8.14 & 5.01 & 10.50 & 8.24 \\
Democracy (age) $(\ln )$ & 2.73 & 0 & 5.25 & 2.40 \\
\hline
\end{tabular}

†0 Observations 
Table 4: Electoral Alliances in Panama 1994-2009

\begin{tabular}{|c|c|c|c|}
\hline 1994 & 1999 & 2004 & 2009 \\
\hline $\begin{array}{c}\text { United People's } \\
\text { Alliance } \\
\text { PRD } \\
\text { PALA } \\
\text { LIBRE }\end{array}$ & $\begin{array}{c}\text { New National Alliance } \\
\text { PRD } \\
\text { PLN } \\
\text { SOLID } \\
\text { MPE }\end{array}$ & $\begin{array}{c}\frac{\text { New Fatherland }}{\text { PRD }} \\
\text { PP* }\end{array}$ & $\begin{array}{c}\text { One Country for All } \\
\text { PRD } \\
\text { PP* } \\
\text { PL }\end{array}$ \\
\hline $\begin{array}{c}\text { Democratic Alliance } \\
\text { PPAN } \\
\text { PL } \\
\text { PLA } \\
\text { UDI }\end{array}$ & $\begin{array}{c}\text { Union for Panama } \\
\text { PPAN } \\
\text { MOLIRENA } \\
\text { CD } \\
\text { MORENA }\end{array}$ & $\begin{array}{c}\text { Vision of the Country } \\
\text { PPAN } \\
\text { MOLIRENA } \\
\text { PLN }\end{array}$ & $\begin{array}{c}\text { Alliance for Change } \\
\text { CD } \\
\text { PPAN } \\
\text { UP** } \\
\text { MOLIRENA }\end{array}$ \\
\hline $\begin{array}{c}\frac{\text { Change'94 }}{\text { MOLIRENA }} \\
\text { MORENA } \\
\text { PRC } \\
\text { Front for National } \\
\text { Unity } \\
\text { SOLID } \\
\text { MUN }\end{array}$ & $\begin{array}{c}\text { Opposition Action } \\
\text { Alliance } \\
\text { PDC } \\
\text { PL } \\
\text { PRC } \\
\text { PNP }\end{array}$ & & \\
\hline $\begin{array}{l}\text { PDC, MPE and PPD } \\
\text { ran independent of any } \\
\text { alliance }\end{array}$ & & $\begin{array}{l}\text { CD and SOLID ran } \\
\text { independently of any } \\
\text { alliance }\end{array}$ & $\begin{array}{l}\text { VMP and Independent } \\
\text { Candidates ran } \\
\text { independently of any } \\
\text { alliance }\end{array}$ \\
\hline
\end{tabular}


Table 5: Effects of Corruption Allegations on Vote for the Incumbent

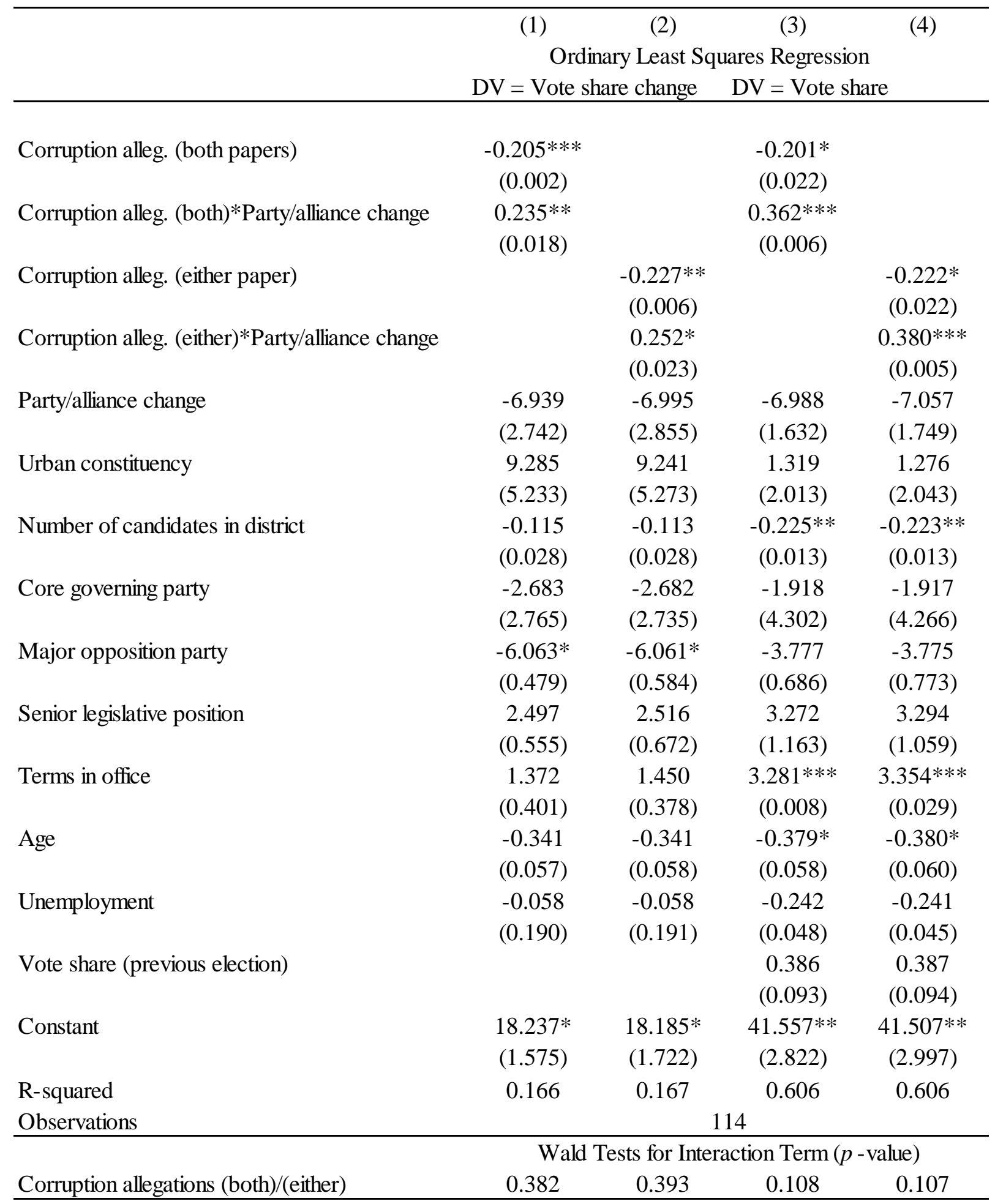

Note: The dependent variables are vote share change (models $1 \& 2$ ) and vote share of incumbent (models $3 \& 4$ ); robust standard errors clustered on election year in parentheses, $* * * \mathrm{p}<0.01, * * \mathrm{p}<0.05, * \mathrm{p}<0.1$; the Wald tests report the $p$-value for the corruption allegations variable plus its interaction with party/alliance change. 
Figure 1: Marginal Effect of Corruption Allegation while varying Party/Alliance Change

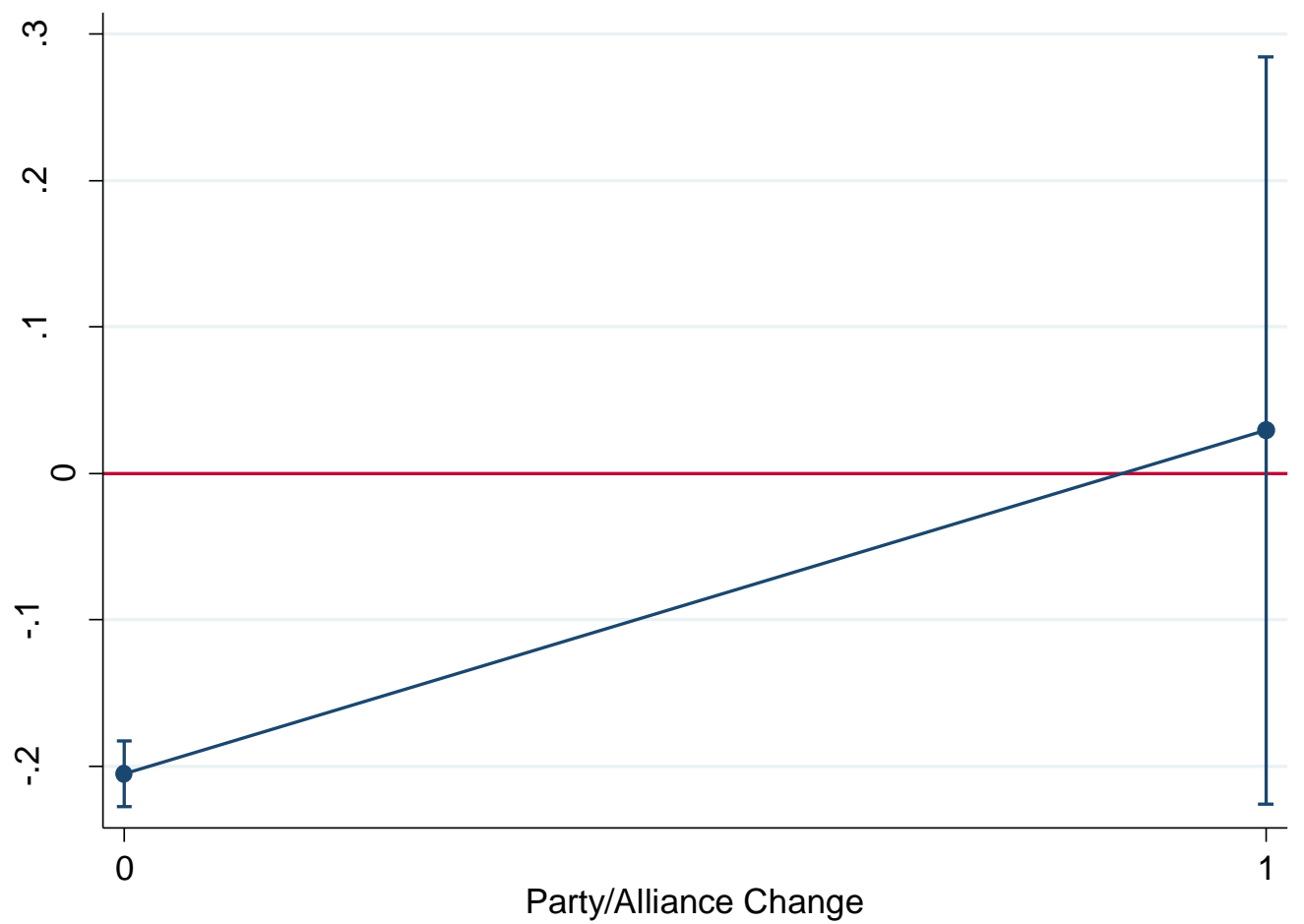

Note: The figure shows the marginal effect of corruption allegation (with $95 \%$ confidence intervals) while varying party/alliance change. 
Appendix 1: Countries in the Analysis

\begin{tabular}{llll}
\hline Albania & Ecuador & Korea, Rep. & Philippines \\
Argentina & El Salvador & Latvia & Poland \\
Australia & Estonia & Lesotho & Portugal \\
Austria & Finland & Lithuania & Romania \\
Bangladesh & France & Macedonia & Senegal \\
Belgium & Germany & Madagascar & Slovak Republic \\
Benin & Ghana & Malawi & Slovenia \\
Bolivia & Greece & Mali & South Africa \\
Botswana & Guatemala & Mauritius & Spain \\
Brazil & Guyana & Mexico & Sri Lanka \\
Bulgaria & Honduras & Mongolia & Sweden \\
Canada & Hungary & Namibia & Switzerland \\
Chile & India & Nepal & Thailand \\
Colombia & Indonesia & Netherlands & Trinidad and Tobago \\
Costa Rica & Ireland & New Zealand & Turkey \\
Croatia & Israel & Nicaragua & Ukraine \\
Cyprus & Italy & Norway & United Kingdom \\
Czech Republic & Jamaica & Panama & United States \\
Denmark & Japan & Paraguay & Uruguay \\
Dominican Republic & Kenya & Peru & Venezuela \\
\hline
\end{tabular}




\begin{tabular}{|c|c|}
\hline $\begin{array}{l}\text { Variable: } \\
\text { Comparative Analysis }\end{array}$ & Source: \\
\hline Corruption perceptions & $\begin{array}{l}\text { The Worldwide Governance Indicators: Methodology and Analytical Issues, Kaufmann, Kraay, and } \\
\text { Mastruzzi (2010). }\end{array}$ \\
\hline $\begin{array}{l}\text { Party system institutionalization } \\
\text { (party age) }\end{array}$ & $\begin{array}{l}\text { Beck et al.'s (2001) Database of Political Institutions ( } 2010 \text { version). Average age of the first and } \\
\text { second largest governing parties and the largest opposition party or any subset of these for which } \\
\text { party age is known. }\end{array}$ \\
\hline $\begin{array}{l}\text { Party system institutionalization } \\
\text { (electoral volatility) }\end{array}$ & $\begin{array}{l}\text { Mainwaring, Espana, and Gervasoni's (2009). Total volatility captures the "absolute value of change } \\
\text { in the percentage of votes gained or lost by each party from election to the next" . }\end{array}$ \\
\hline Effective no. of electoral parties & Gallagher and Mitchell (2008), augmented using Golder (2005) and calculations by the authors. \\
\hline Ideological structuration & $\begin{array}{l}\text { Keefer and Stasavage (2003), included in Beck et al's (2001) Database of Political Institutions (2010 } \\
\text { version). These data record the extent to which the chief executive's party, the three largest } \\
\text { government parties, and the largest opposition party in a country adopt programmatic positions with } \\
\text { respect to economic policy (left, centre, or right). We follow Keefer's (2011) approach and calculate } \\
\text { what proportion of these parties adopt programmatic policy positions. }\end{array}$ \\
\hline Decentralization & $\begin{array}{l}\text { Beck et al.'s (2001) Database of Political Institutions ( } 2010 \text { version). Decentralization records the } \\
\text { extent to which countries have autonomous, locally elected governments. }\end{array}$ \\
\hline Executive president & Svolik's (2008). Indicator: executive presidents. \\
\hline Tradeopenness & $\begin{array}{l}\text { World Bank Development Indicators: Measured by the sum of a country's imports and exports as a } \\
\text { share of GDP - missing country-years were completed using import and export data as reported in } \\
\text { the IMF's International Financial Statistics. }\end{array}$ \\
\hline GDP per capita & Real GDP per capita (in constant 2000 US\$), World Bank Development Indicators. \\
\hline Democracy (polity score) & $\begin{array}{l}\text { Polity IV Project, http://www.systemicpeace.org/inscr/inscr.htm. Throughout we employ the polity } 2 \\
\text { score. }\end{array}$ \\
\hline Democracy (age) & $\begin{array}{l}\text { Calculation based on Polity IV Project, http://www.systemicpeace.org/inscr/inscr.htm. Throughout } \\
\text { we employ the polity } 2 \text { score. }\end{array}$ \\
\hline Ethnolinguistic fragmentation & Alesina et. al.’s (2003) ethnolinguistic fragmentation index. \\
\hline Electoral system data & $\begin{array}{l}\text { Beck et al.'s (2001) Database of Political Institutions ( } 2010 \text { version), augmented using Regan and } \\
\text { Clark (2010) and Golder (2005). }\end{array}$ \\
\hline \multicolumn{2}{|l|}{ Panama Analysis: } \\
\hline Vote share & National Assembly of the Republic of Panama. District level electoral results. \\
\hline Corruption allegations & $\begin{array}{l}\text { El Panama America, La Prensa. Count that records all instances in which deputies were alleged to } \\
\text { be involved in the misuse of public office for personal or political gain or to have tolerated corruption } \\
\text { by bureaucrats. }\end{array}$ \\
\hline Party/alliance change & Change (1, otherwise 0$)$. National Assembly of the Republic of Panama. \\
\hline Urban constituency & Urban constituency (1, rural 0). Guevara Mann (2011) \\
\hline Number of candidates in district & National Assembly of the Republic of Panama. District level electoral results. \\
\hline Core governing party & $\begin{array}{l}\text { Party that controls the largest number of seats in the governing coalition (1, otherwise } 0) \text { : PPAN } \\
\text { (1999-2004), PRD (2004-2009). }\end{array}$ \\
\hline Major opposition party & Party that leads the opposition (1, otherwise 0): PRD (1999-2004), PPAN (2004-2009). \\
\hline Senior legislative position & $\begin{array}{l}\text { Assembly president or party leader (1, otherwise } 0) \text {. Tribunal Electoral de Panama } \\
\text { (http://www.tribunal-electoral.gob.pa/html/) }\end{array}$ \\
\hline Terms in office & $\begin{array}{l}\text { Number of legislative terms served. Tribunal Electoral de Panama( http://www.tribunal- } \\
\text { electoral.gob.pa/html/) }\end{array}$ \\
\hline Age & $\begin{array}{l}\text { Legislator biographies, websites, officical documentation. Missing for a quarter of the deputies for } \\
\text { which we imputed age. }\end{array}$ \\
\hline Unemployment & $\begin{array}{l}\text { Panama National Institute of Statistics (http://www.contraloria.gob.pa/inec/acerca/Default.aspx). } \\
\text { Rates of unemployment in Panama, at province-level (with greater breakdown for Panama City). }\end{array}$ \\
\hline
\end{tabular}




\section{References}

Adsera, Alicia, Carles Boix, and Mark Payne. 2003. "Are You Being Served? Political Accountability and Quality of Government." Journal of Law, Economics, and Organisation 19 (2):445-90.

Afrobarometer. 2006. "The Status of Democracy, 2005-2006: Findings from Afrobarometer Round 3 for 18 Countries." Afrobarometer Briefing Paper 40. http://afrobarometer.org/publications/afrobarometer-briefing-papers/item/231-thestatus-of-democracy-2005-2006-findings-from-afrobarometer-round-3-for-18countries.

Alesina, Alberto, Arnaud Devleeschauwer, William Easterly, Sergio Kurlat, and Romain Wacziarg. 2003. "Fractionalization." Journal of Economic Growth 8 (2):155-94.

Amorim Neto, Octavio, and Gary Cox, 1997. "Electoral institutions, cleavage structures, and the number of parties." American Journal of Political Science 41(1):149-174.

Banks, Jeffrey, and Rangarajan Sundaram. 1993. "Adverse Selection and Moral Hazard in a Repeated Elections Model." In Political Economy: Institutions, Competition and Representation, ed. W. Barnett, N. Schofield and M. Hinich. Cambridge: Cambridge University Press.

Bartolini, Stefano, and Peter Mair. 1990. "Policy competition, spatial distance and electoral instability." West European Politics 13 (4):1-16.

Beck, Thorsten, George Clarke, Alberto Groff, Philip Keefer, and Patrick Walsh. 2001. "New Tools in Comparative Political Economy: The Database of Political Institutions." The World Bank Economic Review 15 (1):165-76.

Berry, William D., Matt Golder, and Daniel Milton. 2012. Improving tests of theories positing interaction. The Journal of Politics, 74(3), 653-671.

Besley, Timothy and Anne Case. 1995. Does political accountability affect economic policy choices? Evidence from gubernatorial term limits. Quarterly Journal of Economics,110(3):769-798.

Besley, Timothy and Valentino Larcinese. 2011. "Working or shirking?: expenses and attendance in the UK parliament." Public Choice 146 (3-4): 291-317.

Birch, Sarah. 2003. Electoral Systems and Political Transformation in Postcommunist Europe. Basingstoke, UK: Palgrave.

Bleck, Jaimie, and Nicolas Van de Walle. 2013. "Valence Issues in African Elections Navigating Uncertainty and the Weight of the Past." Comparative Political Studies, 46(11), 1394-1421.

Boix, Carles. 2007. "The Emergence of Parties and Party Systems" In The Oxford Handbook of Comparative Politics, eds. C. Boix and S. Stokes. Oxford: Oxford University Press. 
Chang, Eric, and Miriam Golden. 2006. "Electoral Systems, District Magnitude and Corruption." British Journal of Political Science 37 (1):115-37.

Chang, Eric, Miriam Golden, and Seth Hill. 2010. "Legislative Malfeasance and Political Accountability." World Politics 62 (2):177-220.

Clarke, Kevin A. and Randall W. Stone, 2008. "Democracy and the Logic of Political Survival." American Political Science Review 102(3): 387-392.

Croissant, Aurel, and Philip Völkel. 2010. "Party system types and party system institutionalization: Comparing new democracies in East and Southeast Asia." Party Politics, first published on December 21, 2010 doi:10.1177/1354068810380096.

Della Porta, Donatella. 2004. "Political Parties and Corruption: Ten Hypotheses on Five Vicious Circles." Crime, Law and Social Change 42 (1):35-60.

Eggers, Andrew, and Alexander Fisher. 2011. "Electoral Accountability and the UK Parliamentary Expenses Scandal: Did Voters Punish Corrupt MPs?" Political Science and Political Economy Working Paper 8/2011. London: London School of Economics.

Ferejohn, John. 1986. "Incumbent performance and electoral control." Public Choice 50 (1):5-25.

Figlio, David N. 2000. "Political shirking, opponent quality, and electoral support." Public Choice, 703(3-4): 271-28.

Fisman, Raymond, and Roberta Gatti. 2002. "Decentralization and corruption: evidence across countries." Journal of Public Economics 83 (3):325-45.

Gallagher, Michael, and Paul Mitchell. 2008. The Politics of Electoral Systems. Oxford: Oxford University Press.

Gerring, John, and Strom C. Thacker. 2004. "Political Institutions and Corruption: The Role of Unitarism and Parliamentarism." British Journal of Political Science 34 (2):295330.

Gerring, John, and Strom C. Thacker. 2005. "Do Neoliberal Policies Deter Political Corruption?" International Organization 59 (1):233-54.

Giliomee, Hermann. 1998. "South Africa's Emerging Dominant Party Regime." Journal of Democracy 9 (4):128-42.

Golder, Matthew. 2005. "Democratic Electoral Systems Around the World: 1945-2000." Electoral Studies 24 (1):103-21.

Golder, Matthew and Gabriella Lloyd. 2014. "Re-evaluating the Relationship between Electoral Rules and Ideological Congruence." European Journal of Political Research 
53 (1): 200-212.

Guevara Mann, Carlos. 2000. "Patronage Distribution, Party Switching, and Electoral Manipulation by Panamanian Legislators: The Electoral Connection." Latin American Studies Association. Miami.

2011. Political Careers, Corruption, and Impunity. Notre Dame, Indiana: Notre Dame University Press.

Hassan, Mazen. 2011. Determinants of Party System Institutionalization in New Democracies: A Cross-National Study, Department of Politics and International Relations, University of Oxford, Oxford.

Hug, Simon. 2000. Studying the Electoral Success of New Political Parties A Methodological Note. Party Politics, 6(2), 187-197.

Jones, Michael. 2005. "The Role of Parties and Party Systems in the Policymaking Process." Workshop on State Reform, Public Policies and Policymaking Processes. InterAmerican Development Bank, Washington, D.C.: http://www.iadb.org/res/publications/pubfiles/pubs-310.pdf.

Kaufmann, Daniel, Art Kraay. 2002. "Growth Without Governance" Work Bank Policy Research Working Paper 2928: World Bank.

Kaufmann, Daniel, Art Kraay, and Massimo Mastruzzi. 2007. "The Worldwide Governance Indicators Project: Answering the Critics." Work Bank Policy Research Working Paper 4149: World Bank

Kaufmann, Daniel, Art Kraay, and Massimo Mastruzzi. 2010. "The Worldwide Governance Indicators: Methodology and Analytical Issues.” Work Bank Policy Research Working Paper 5430: World Bank.

2002. "Governance Matters II: Updated Indicators for 2000/01." Work Bank Policy Research Working Paper 2772: World Bank.

Keefer, Philip. 2011. "Collective Action, Political Parties and Pro-Development Public Policy." Asian Development Review 28 (1):94-118.

Keefer, Philip, and David Stasavage. 2003. "The Limits of Delegation: Veto Players, Central Bank Independence, and the Credibility of Monetary Policy." American Political Science Review 97 (3):407-23.

Key, Valdimer Orlando. 1936. Techniques of political graft in the United States. Chicago: University of Chicago Press.

Kiewiet, D. Roderick, and Langche Zeng. 1993. "An Analysis of Congressional Career Decisions, 1947-1986." The American Political Science Review 87 (4):928-41.

Kuenzi, Michelle, and Gina Lambright. 2001. "Party System Institutionalization in 30 African Countries." Party Politics 7 (4):437-68. 
_ 2005. "Party Systems and Democratic Consolidation in Africa's Electoral Regimes." Party Politics 11 (4):423-46.

Kunicova, Jana, and Susan Rose-Ackerman. 2005. "Electoral Rules and Constitutional Structures as Constraints on Corruption." British Journal of Political Science 35 (4):573-606.

Kurer, Oskar. 2001. "Why Do Voters Support Corrupt Politicians." In The Political Economy of Corruption, ed. A. Jain. London: Routledge. 63-86.

LAPOP. 2010. The Americas Barometer. www.LapopSurveys.org.

Latinobarometro. 2008. "Latinobarometro 2008." Santiago.

Lieberman, Evan. 2005. "Nested Analysis as a Mixed-Method Strategy for Comparative Research." American Political Science Review 99 (3):435-52.

Lindstädt, René, and Ryan J. Vander Wielen. 2011. "Timely shirking: time-dependent monitoring and its effects on legislative behavior in the US Senate." Public Choice $148(1-2): 119-148$.

Mainwaring, Scott. 1993. "Presidentialism, Multipartism, and Democracy." Comparative Political Studies 26 (2):198-228.

Mainwaring, Scott, Annabella Espana, and Carlos Gervasoni. 2009. "Extra System Electoral Volatility and the Vote Share of Young Parties." Annual Meeting of the Canadian Political Science Association.

Mainwaring, Scott, and Timothy Scully, eds. 1995. Building Democratic Institutions: Party Systems in Latin America. Stanford: Stanford University Press.

Mainwaring, Scott, and Mariano Torcal. 2006. "Party System Institutionalization and Party System Theory after the Third Wave of Democratization." In Handbook of Political Parties, ed. Richard Katz and W. Crotty. London: Sage Publishers.

Mainwaring, Scott, and Edurne Zoco. 2007. "Political Sequences and the Stabilization of Interparty Competition Electoral Volatility in Old and New Democracies." Party politics 13(2): 155-178.

Montinola, Gabriela, and Robert Jackman. 2002. "Sources of Corruption: A Cross-Country Study." British Journal of Political Science 32 (1):147-70.

Moore, Michael K., and John R. Hibbing. 1998. "Situational Dissatisfaction in Congress: Explaining Voluntary Departures." The Journal of Politics 60 (04):1088-107.

Moser, Robert G., and Ethan Scheiner. 2012. Electoral systems and political context: How the effects of rules vary across new and established democracies. New York: Cambridge University Press. 
Parker, Glenn R., and Stephen C. Powers. 2002. "Searching for symptoms of political shirking: congressional foreign travel." Public Choice 110(1-2): 173-191.

Payne, J. Mark, Daniel Zovatto G., Fernando Carillo Flores, and Andres Allamand Zavala. 2002. Democracies in Development: Politics and Reform in Latin America. Washington, DC: The Inter-American Development Bank.

Perez, Orlando. 2000. Post-Invasion Panama: The Challenges of Democratization in the New World Order. Oxford: Lexington Books.

Persson, Anna, Bo Rothstein, and Jan Teorell. 2010. "The Failure of Anti-Corruption Policies: A Theoretical Mischaracterization of the Problem." QoG Working Paper Series.

Persson, Torsten, and Guido Tabellini. 2003. The economic effects of constitutions. Cambridge, MA: MIT Press.

Powell, G. Bingham. 2000. Elections as instruments of democracy: majoritarian and proportional visions. London: Yale University Press.

Reed, SR. 1999. "Political Reform in Japan: Combining Scientific and Historical Analysis." Social Science Japan Journal 2 (2):177-93.

Regan, Patrick, and Dave Clark. 2010. "The Institutions and Elections Project." Binghamton University.

Reporters without Borders. 2011. http://en.rsf.org/report-panama, 186.html; http://en.rsf.org/report-uruguay, 194.html.

Roberts, Kenneth M., and Erik Wibbels. 1999. "Party Systems and Electoral Volatility in Latin America: A Test of Economic, Institutional, and Structural Explanations." The American Political Science Review 93 (3):575-90.

Rocamora, Joel. 1998. "Philippine Political Parties, Electoral System and Political Reform". Philippines International Review (Spring): 1-10.

Rose, Richard, Neil Munro and Stephen White. 2001. "Voting in a Floating Party System: The 1999 Duma Election.” Europe-Asia Studies 53 (3): 419-443.

Rothenberg, Lawrence S., and Mitchell S. Sanders. 2000. "Severing the electoral connection: shirking in the contemporary congress." American Journal of Political Science 44 (2): 316-325.

Samuels, David, and Matthew Soberg Shugart. 2010. Presidents, parties, and prime ministers: how the separation of powers affects party organization and behavior. Cambridge: Cambridge University Press.

Sanchez, Omar. 2008. "Transformation and Decay: The De-Institutionalization of Party Systems in South America." Third World Quarterly 29 (2):315-37. 
Schedler, Andreas. 1995. "Under- and Overinstitutionalization: Some Ideal Typical Propositions Concerning New and Old Party Systems." In Kellogg Institute Working Papers.

Schedler, Andreas. 1999. "Conceptualizing Accountability." In The Self-Restraining State, eds. A. Schedler, L Diamond and M. Plattner. Boulder: Lynne Rienner Publishers.

Scheiner, Ethan. 2005. "Pipelines of Pork: Japanese Politics and a Model of Local Opposition Party Failure." Comparative Political Studies 38 (7):799-823.

Shabad, Goldie, and Kazimierz M. Slomczynski. 2004. "Inter-Party Mobility among Parliamentary Candidates in Post-Communist East Central Europe." Party Politics 10 (2):151-76.

Sikk, Allan. 2005. "How unstable? Volatility and the genuinely new parties in Eastern Europe." European Journal of Political Research 44 (3):391-412.

Sovey, Allison, and Donald Green. 2011. "Instrumental Variables Estimation in Political Science: A Readers' Guide." American Journal of Political Science 55 (1):188-200.

Svolik, Milan 2008. "Authoritarian Reversals and Democratic Consolidation." American Political Science Review 102 (2):153-68.

Tavits, Margit. 2007. "Clarity of Responsibility and Corruption." American Journal of Political Science 51 (1):219-29.

2008. "On the linkage between electoral volatility and party system instability in Central and Eastern Europe." European Journal of Political Research 47 (5):537-55.

2008. The role of parties' past behavior in coalition formation. American Political Science Review, 102(04), 495-507

2011. Power within parties: The strength of the local party and MP independence in postcommunist Europe. American Journal of Political Science, 55(4), 923-936.

2013. Post-communist democracies and party organization. Cambridge and New York: Cambridge University Press.

Stokes, Susan C. 2001. Mandates and democracy: Neoliberalism by surprise in Latin America. Cambridge and New York: Cambridge University Press.

Teehankee, Julio. 2006. 2006. "Consolidation or Crisis of Clientelistic Democracy? The 2004 Synchronized Elections in the Philippines." In Between Consolidation and Crisis:

Elections and Democracy in Five Nations in Southeast Asia, eds. Aurel Croissant and Beate Martin. Berlin: Lit Verlag, 215-276.

Theriault, Sean M. 1998. "Moving Up or Moving Out: Career Ceiling and Congressional Retirement." Legislative Studies Quarterly 23 (3):419-33.

Transparency International. 2013. Global Corruption Barometer: 
http://www.transparency.org/gcb2013/report.

Treisman, Daniel. 2000. "The Causes of Corruption: A Cross-national Study." Journal of Public Economics 76 (3):399-457.

- 2007. "What Have We Learned About the Causes of Corruption from Ten Years of Cross-National Empirical Research?" Annual Review of Political Science 10 (1):21144.

Ufen, Andreas. 2007. "Political Party and Party System Institutionalization in Southeast Asia: A Comparison of Indonesia, the Philippines, and Thailand." GIGA Working Paper Series 44: 1-30.

Wooldridge, Jeffrey M. 2002. Econometric Analysis of Cross Section and Panel Data. Cambridge, MA: MIT Press.

Welch, Susan, and John R. Hibbing. 1997. "The Effects of Charges of Corruption on Voting Behavior in Congressional Elections, 1982-1990." The Journal of Politics 59 (01):226-39.

Zielinski, Jakub, Kazimierz M. Slomczynski, and Goldie Shabad. 2005. "Electoral Control in New Democracies: The Perverse Incentives of Fluid Party Systems." World Politics 57 (3):365-95. 


\section{Supplementary Information}

Table SI 1: Descriptive Statistics (Comparative Analysis)

\begin{tabular}{|c|c|c|c|c|}
\hline & \multicolumn{3}{|c|}{ Standard } & \multirow[b]{2}{*}{ Maximum } \\
\hline & Mean & Deviation & Minimum & \\
\hline Corruption Perceptions & 0.34 & 0.99 & -1.46 & 2.35 \\
\hline Party System Institutionalization (ln Party Age) & 3.19 & 0.91 & 1.13 & 5.00 \\
\hline Effective Number of Electoral Parties (ln) & 1.43 & 0.48 & 0.52 & 3.30 \\
\hline Ideological Structuration & 0.83 & 0.25 & 0 & 1 \\
\hline Decentralization & 0.98 & 0.87 & 0 & 2 \\
\hline Executive President & 0.59 & 0.49 & 0 & 1 \\
\hline Tradeopenness & 0.78 & 0.37 & 0.19 & 2.05 \\
\hline GDP Per Capita (ln) & 8.14 & 1.49 & 5.01 & 10.50 \\
\hline Democracy (Polity Score) & 8.49 & 1.44 & 6 & 10 \\
\hline Democracy (ln Age) & 2.73 & 1.28 & 0 & 5.25 \\
\hline Ethnolinguistic Fragmentation & 0.38 & 0.23 & 0 & 0.88 \\
\hline Proportional Representation & 0.41 & 0.49 & 0 & 1 \\
\hline Plurality (First-Past- the-Post) & 0.12 & 0.33 & 0 & 1 \\
\hline Open Lists & 0.43 & 0.49 & 0 & 1 \\
\hline Open Lists*Proportional Representation & 0.08 & 0.27 & 0 & 1 \\
\hline Party System Institutionalization (ln Party Age 1980s) & 3.37 & 0.92 & 1.10 & 5.07 \\
\hline Party System Institutionalization (Volatility) & 22.22 & 12.05 & 3.22 & 49.94 \\
\hline Former Soviet Union & 0.05 & 0.22 & 0 & 1 \\
\hline Middle East & 0.02 & 0.16 & 0 & 1 \\
\hline Central and South America & 0.26 & 0.44 & 0 & 1 \\
\hline Asia & 0.12 & 0.33 & 0 & 1 \\
\hline Africa & 0.15 & 0.36 & 0 & 1 \\
\hline Observations & & & & \\
\hline
\end{tabular}




\section{SI 2: Robustness}

Table SI 2: Robustness to Alternative Specifications

\begin{tabular}{|c|c|c|c|c|}
\hline & $\begin{array}{c}(1) \\
\text { Volatility }\end{array}$ & $\begin{array}{c}\text { (2) } \\
\text { Party Age } \\
\text { orthogonalized }\end{array}$ & $\begin{array}{c}(3) \\
\text { Restricted } \\
\text { Sample: Polity } 7\end{array}$ & $\begin{array}{c}\text { (4) } \\
\text { Restricted } \\
\text { Sample: Polity } 8 \\
\end{array}$ \\
\hline Party System Institutionaliz'n (volatility) & $\begin{array}{c}-0.019 * * \\
(0.008)\end{array}$ & & & \\
\hline $\begin{array}{l}\text { Party System Institutionaliz'n (ln party age, } \\
\text { orthogonalized) }\end{array}$ & & $\begin{array}{l}0.115 * * \\
(0.056)\end{array}$ & & \\
\hline Party System Institutionaliz'n (ln party age) & & & $\begin{array}{l}0.216 * * * \\
(0.080)\end{array}$ & $\begin{array}{c}0.236 * * \\
(0.099)\end{array}$ \\
\hline Party System Fragmentation & $\begin{array}{c}0.340 \\
(0.265)\end{array}$ & $\begin{array}{c}0.197 \\
(0.134)\end{array}$ & $\begin{array}{l}0.351 * * \\
(0.164)\end{array}$ & $\begin{array}{c}0.314 \\
(0.192)\end{array}$ \\
\hline Ideological Structuration & $\begin{array}{c}0.543 \\
(0.393)\end{array}$ & $\begin{array}{l}0.611 * * \\
(0.236)\end{array}$ & $\begin{array}{l}0.800 * * \\
(0.319)\end{array}$ & $\begin{array}{c}0.894 * * \\
(0.409)\end{array}$ \\
\hline Decentralization & $\begin{array}{l}-0.029 \\
(0.104)\end{array}$ & $\begin{array}{c}0.017 \\
(0.068)\end{array}$ & $\begin{array}{l}-0.040 \\
(0.076)\end{array}$ & $\begin{array}{l}-0.025 \\
(0.092)\end{array}$ \\
\hline Executive President & $\begin{array}{c}0.143 \\
(0.162)\end{array}$ & $\begin{array}{c}0.048 \\
(0.120)\end{array}$ & $\begin{array}{c}0.062 \\
(0.129)\end{array}$ & $\begin{array}{c}0.119 \\
(0.152)\end{array}$ \\
\hline Tradeopenness & $\begin{array}{c}0.108 \\
(0.217)\end{array}$ & $\begin{array}{c}0.099 \\
(0.136)\end{array}$ & $\begin{array}{c}0.095 \\
(0.161)\end{array}$ & $\begin{array}{c}0.059 \\
(0.189)\end{array}$ \\
\hline GDP per capita (ln) & $\begin{array}{c}0.384 * * * \\
(0.076)\end{array}$ & & $\begin{array}{c}0.358 * * * \\
(0.076)\end{array}$ & $\begin{array}{c}0.374 * * * \\
(0.097)\end{array}$ \\
\hline Democracy (ln, age) & $\begin{array}{c}0.118 \\
(0.089)\end{array}$ & & $\begin{array}{l}0.128 * \\
(0.064)\end{array}$ & $\begin{array}{c}0.129 \\
(0.081)\end{array}$ \\
\hline GDP per capita (ln, orthogonalized) & & $\begin{array}{c}0.750 * * * \\
(0.085)\end{array}$ & & \\
\hline Democracy (ln age, orthogonalized) & & $\begin{array}{c}0.128 * * \\
(0.048)\end{array}$ & & \\
\hline Constant & $\begin{array}{c}-3.500 * * * \\
(0.807)\end{array}$ & $\begin{array}{l}-0.389 \\
(0.359)\end{array}$ & $\begin{array}{c}-4.645^{* * *} \\
(0.705)\end{array}$ & $\begin{array}{c}-4.924 * * * \\
(0.870)\end{array}$ \\
\hline Region Dummies & Yes & Yes & Yes & Yes \\
\hline $\mathrm{R}^{2}$ & 0.845 & 0.851 & 0.853 & 0.854 \\
\hline Observations & 52 & 80 & 66 & 55 \\
\hline
\end{tabular}

Note: The dependent variable is perceptions of corruption control; standard errors in parentheses; $* \mathrm{p}<.10, * * \mathrm{p}<.05, * * * \mathrm{p}<.01$ (two-tailed test).

Table SI 2 presents additional analyses that test the robustness of the results from our main model 2 (cf. Table 1). In model 1, we change our main explanatory variable, and employ electoral volatility instead of average party age as our measure of party system institutionalization. As noted in the main text, electoral volatility, which captures aggregate party system stability, is driven by the entry and exit of parties into the political system and by the stability of their support. We employ Mainwaring, Espana and Gervasoni's (2009) 
measure for total volatility aggregated over the period $1990-2002,{ }^{25}$ which captures the "absolute value of change in the percentage of votes gained or lost by each party from one election to the next" (Mainwaring, Espana and Gervasoni 2009: 1) and is available for a reduced sample of 52 countries. Party systems that display higher levels of volatility are less institutionalized and feature lower (weaker) control of corruption scores as anticipated. In model 2, we address the fact that party system institutionalization, the age of democracy and wealth are correlated by orthogonalizing these three variables and replacing party system institutionalization with the residuals from the auxiliary regression. This procedure attributes all shared variation between party system institutionalization, wealth and democracy to the two latter variables and allows us to examine the effect of party system institutionalization on perceived corruption, net of that shared variance (Clarke and Stone 2008). As a result, the coefficients on wealth and age of democracy increase in size while the coefficient for party system institutionalization is slightly reduced, but the effect remains sizable and statistically significant. In models 3 and 4, we change our definition of democracy, and successively restrict the sample to focus on increasingly high quality democracies. In a first step we apply a polity threshold of 7 , and in a second step a threshold of 8 . The results are robust to all of these alternative specifications.

\section{References}

Clarke, Kevin A. and Randall W. Stone, 2008. "Democracy and the Logic of Political Survival." American Political Science Review 102(3): 387-392.

Mainwaring, Scott, Annabella Espana, and Carlos Gervasoni. 2009. "Extra System Electoral Volatility and the Vote Share of Young Parties." Annual Meeting of the Canadian Political Science Association.

\footnotetext{
${ }^{25}$ We record electoral volatility over this extended period in order to capture at least two elections per country.
} 
Table SI 3: Descriptive Statistics (Panama)

\begin{tabular}{lcccc}
\hline & & Standard & & \\
& Mean & Deviation & Minimum & Maximum \\
\hline Vote Share Change & -2.17 & 10.05 & -33.7 & 20.1 \\
Vote Share & 26.66 & 12.69 & 2.6 & 66.2 \\
Corruption Allegations (both Papers) & 2.48 & 8.26 & 0 & 65 \\
Corruption Allegations (either Paper) & 2.64 & 8.24 & 0 & 65 \\
Party/Alliance Change & 0.24 & 0.43 & 0 & 1 \\
Urban Constituency & 0.56 & 0.50 & 0 & 1 \\
Number of Candidates in District & 19.72 & 15.40 & 2 & 53 \\
Core Governing Party & 0.39 & 0.49 & 0 & 1 \\
Major Opposition Party & 0.34 & 0.48 & 0 & 1 \\
Senior Legislative Position & 0.07 & 0.26 & 0 & 1 \\
Terms in Office & 1.52 & 0.72 & 1 & 4 \\
Age & 52.21 & 8.05 & 38 & 85 \\
Unemployment Rate (Constituency) & 8.91 & 4.00 & 1.5 & 17.7 \\
Vote Share (Previous Election) & 29.95 & 12.66 & 4.6 & 66.2 \\
\hline Observations & & & 114 & \\
\hline
\end{tabular}




\section{SI 4: The marginal effect of part/alliance change}

This section analyses the additional implications of the interactive relationship between party switching/alliance change and corruption allegations. Berry, Golder and Milton (2012) recommend that researchers test their expectations about the marginal effects of all variables associated with an interaction term. Here we follow their recommendations, present an additional hypothesis and test the marginal effect of a party/alliance change. Given the inherent symmetry of interaction effects, our theory about the interactive relationship between party/alliance change and corruption allegations implies that a party/alliance change always compromises the ability of voters to hold their representatives accountable. Put differently, party/alliance change weakens the impact of a deputy's actions on their electoral performance, including the potentially negative effects of corruption. This should be true for all levels of corruption. This expectation can be summarized as follows:

Hypothesis SI 4: The marginal effect of a party/alliance change is to reduce the impact of deputies' actions on their electoral performance. This effect should be evident across all levels of corruption allegations.

Figure SI 4 enables us to assess this additional hypothesis by graphing the marginal effect of a party/alliance change on the change in the vote share of a deputy across the full range of values of corruption allegations in our data. The figure illustrates that party and alliance changes undermine effective accountability at all levels of corruption allegations. When deputies switch party or alliance, voter assessments of their performance become extremely variable and allegations about a deputy's corruption never have a statistically significant and negative effect on their electoral performance.

This result is consistent with the expectation outlined in Hypothesis SI 4 above and provides further evidence of the importance of party system institutionalization as a factor that 
conditions the effectiveness of electoral accountability. When aspects of low party system institutionalization such as party and alliance changes affect the relationship between voters and their deputies, electoral accountability is compromised.

Figure SI 4: Marginal Effect of Party/Alliance Change while varying Corruption Allegation

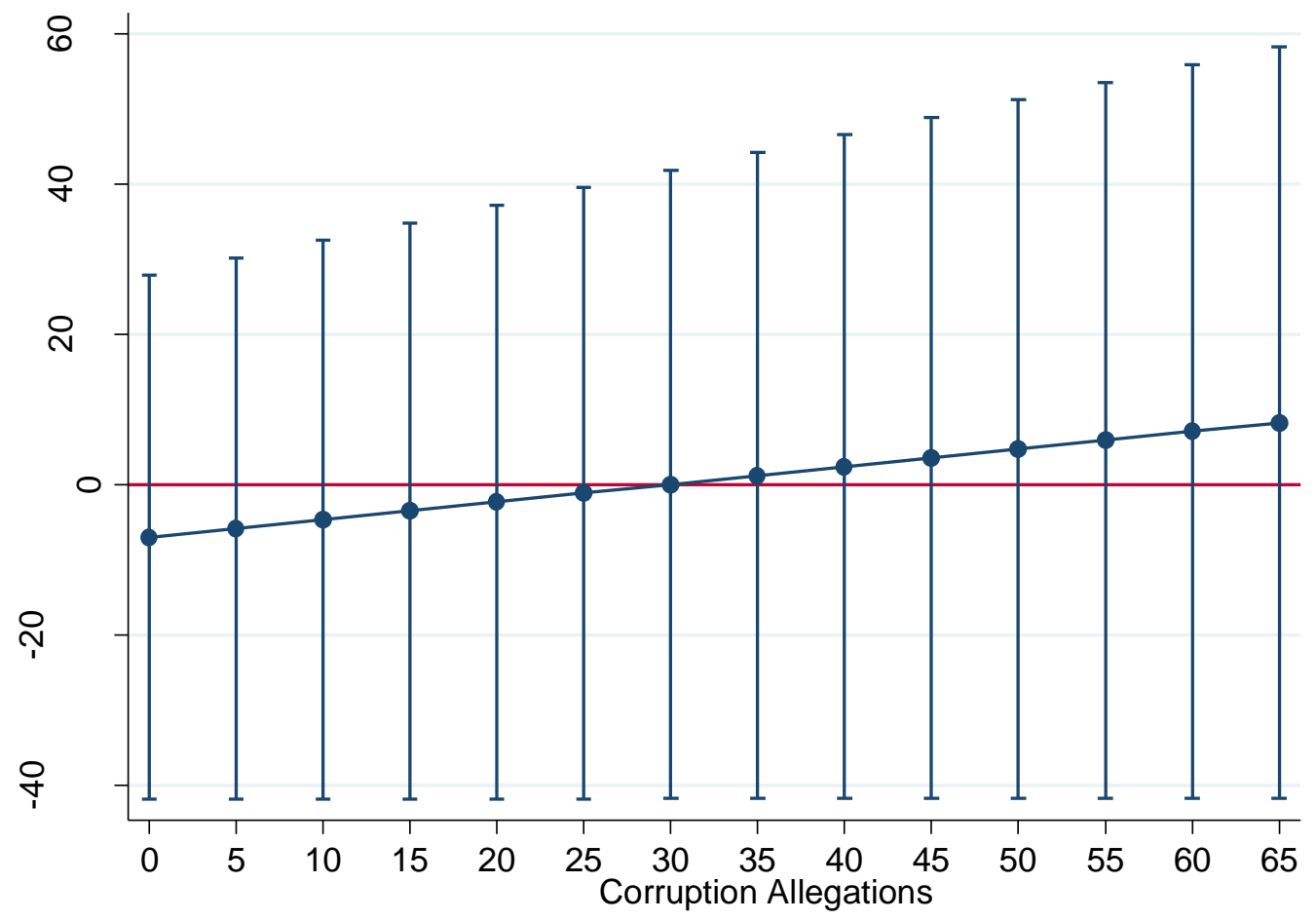

Note: The figure shows the marginal effect of party/alliance change (with $95 \%$ confidence intervals) while varying corruption allegation.

\section{References}

Berry, William D., Matt Golder, and Daniel Milton. 2012. Improving tests of theories positing interaction. The Journal of Politics, 74(3), 653-671. 